\title{
Who wins the race for knowledge-based competitiveness? Comparing European and North American FDI patterns
}

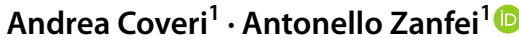

Accepted: 23 November 2021 / Published online: 30 January 2022

(c) The Author(s) 2022

\begin{abstract}
The geographical dispersion of value-added activities triggered by the 'great unbundling' of production has made the race for competitiveness increasingly shaped by the capability of multinational corporations (MNCs) to orchestrate global innovation networks at world scale. However, major differences in the distribution of foreign investments across value chain functions undertaken by MNCs based in different economic areas have drawn little attention in the empirical literature. This work attempts to fill this gap by focusing on the FDI patterns of European and North American MNCs, which have historically played a key role in the internationalization of production and innovation. To this aim, we compare outward FDI flows of European and North American MNCs in manufacturing and knowledgeintensive activities over the period 2003-2017. We show that while European MNCs are key players in global networks of production, they do not reach the heights of North American investors in the dispersion of knowledge-based activities. Most importantly, European MNCs rely on emerging economies more to offshore production than to set up R\&D labs in these countries; by contrast, US-based MNCs are more prone to engage in knowledgeintensive FDIs towards the most dynamic emerging countries (especially China and India, as well as the Four Asian Tigers). Further, we account for the growing role of new entrants in global FDI markets by comparing the advanced economies' foreign investment decisions with those from Chinese MNCs. Drawing from the literature on the globalization of R\&D and cross-border knowledge transmission, a discussion is finally offered on the potential implications of the detected differences in internationalization patterns, together with possible directions for future research.
\end{abstract}

Keywords Internationalization of innovation - Foreign direct investment - Multinational corporation · Europe $\cdot$ North America $\cdot$ Emerging economies $\cdot$ Global value chains

JEL Classification F21 $\cdot$ F23 $\cdot$ L23 $\cdot$ O32

Antonello Zanfei

antonello.zanfei@uniurb.it

Andrea Coveri

andrea.coveri@uniurb.it

1 Department of Economics, Society and Politics, University of Urbino, Urbino, Italy 


\section{Introduction}

In last decades, ever lower transportation, communication, and trading costs, combined with the relentless search for low-cost production inputs and strategic assets, fostered the worldwide dislocation of value-added activities. This process has given rise to what has been dubbed as the "great unbundling" of productive functions at the global level (Baldwin, 2006, 2013). Multinational corporations (MNCs) play a key role in this new economic environment due to their unique capacity to profitably orchestrate global production and innovation networks (Buckley, 2011; Buckley \& Strange, 2015; De Marchi et al., 2014). Their cross-border investment decisions represent a crucial ingredient in the race to gain access to, and exploit, geographically dispersed sources of competitive advantages. In fact, foreign direct investments (FDIs) in different value chain activities make it possible for MNCs to fully exploit their own proprietary assets, but also to explore, evaluate, absorb, and recombine local competencies (Castellani \& Zanfei, 2006; Meyer et al., 2011). Foreign activities in the most upstream, knowledge-intensive functions are generally expected to be more prone to generate competitive advantages for investing firms (Griffith et al., 2006; Narula \& Zanfei, 2005; Papanastassiou et al., 2020), and to eventually create reverse knowledge transfer opportunities for home countries (Audretsch et al., 2014; Narula \& Michel, 2010; Rama, 2008; Rammer \& Schmiele, 2008).

However, there appears to be a lack of studies on foreign investment patterns across value chain activities by MNCs' based in different economic areas, combined with the analysis of destination regions involved. In this context, the paper aims to fill three main research gaps. First, while seminal works like the one conducted fifty years ago by Hymer and Rowthorn (1970) had started a promising reflection on the patterns of FDIs of leading economies of the world, very little efforts have been undertaken to empirically test their prediction of a convergence in cross-border investment strategies of European and North American MNCs. Second, the more recent empirical research which has analyzed internationalization processes and R\&D FDIs over the past decades has seldom adopted a comparative perspective and has long been constrained by the lack of longitudinal data, which impeded a systematic analysis of their evolution over time. Third, while it is widely acknowledged that cross-border investments are generally associated with both cost reduction strategies and the international development, absorption and transfer of technology, more reflections are needed on how differences in FDI patterns undertaken by the largest and most advanced investors can affect their long-term competitiveness.

This work makes a step forward in the direction of filling these gaps in extant empirical literature by exploiting the wealth of information provided by the fDi Markets database, which offers details on the value chain activity each FDI refers to, covering all sectors and countries worldwide from 2003 onwards. We investigate the outward FDI patterns in knowledge-intensive and fabrication activities pursued by MNCs based in two leading economic regions, i.e., Europe and North America, and emphasize the key differences that arise when emerging economies are considered as recipients. While the focus of the present analysis is on patterns of FDIs undertaken by EU and North American companies, we also take a brief look to the foreign investment decisions by MNCs based in China to account for the growing role played by new entrants in global markets, and to get insights on how they might affect the global race of competitiveness between leading economic regions.

Our analysis highlights that there has not been the convergence in FDI patterns envisaged by Hymer and Rowthorn (1970), who predicted that the two most advanced regions 
of the world would have entered a market-seeking competition using the less developed markets as a battleground. We rather observe a remarkable and persisting divergence in the FDI strategies undertaken by European and North American MNCs in terms of their functional, sectoral and geographical distribution.

In particular, we confirm that European MNCs are key actors in global networks of production, but we document that they do not reach the heights in terms of internationalization of knowledge-based activities which have been attained by North American MNCs, especially the US-based ones. Furthermore, European MNCs rely on emerging economies more to offshore production than to set up R\&D labs in these countries; by contrast, US-based MNCs are more prone to engage in knowledge-intensive FDIs towards the most dynamic emerging countries (especially China and India, as well as the Four Asian Tigers) than is the case of the Europeans. These diverging patterns are also found in terms of sectoral distribution of FDIs and are largely confirmed by a firm level focus on the top MNCs based in Europe and in North America. In the light of this evidence, which we frame in the broader context marked by the growing competition from emerging countries, we finally provide a discussion on the reasons why North America's MNCs might be better placed in the race to gain crucial technological and cost-based advantages with respect to MNCs from Europe. ${ }^{1}$

The structure of the paper is the following. Section 2 sets the framework for the analysis by examining previous evidence on European and North American MNCs' internationalization patterns and defines the research questions of our contribution. Section 3 presents the fDi Markets database, upon which the empirical investigation relies. Section 4 reports empirical evidence on the different geographical patterns of global investments flows originating from European and North American MNCs, comparing their propensity to promote FDI projects towards emerging economies in knowledge-intensive and manufacturing stages of the value chain. Furthermore, this section shows the dynamics of the offshoring strategies targeting the emerging economies over time, emphasizing critical divergences between the investment strategies of MNCs based in these two leading regions. Section 5 introduces the role of emerging competitors into the picture with a closer focus on the foreign investment decisions of MNCs headquartered in China. In the light of the empirical evidence presented, Sect. 6 provides a discussion on how the observed differences in internationalization patterns may affect the long-term competitiveness of European and North American MNCs. Section 7 draws some concluding remarks, discusses the limitations of this work, and provides insights for future research.

\section{Background literature and research questions}

For a long time, the internationalization of production was synonymous with the internationalization of manufacturing, the latter being the main engine of the global dispersion of value-added activities. Most relevant actors in this motion are MNCs, which have long been localizing manufacturing stages of production abroad in search of production factors, intermediate goods, and attractive markets (Dunning, 1977, 1980; Hymer, 1972, 1976).

\footnotetext{
1 Given the object of the present work, we use interchangeably the expression 'offshoring' and 'captive offshoring' to mean international insourcing-i.e., the internationalization of production through setting up a productive facility in a foreign country_-, although the latter expression would be more accurate as 'offshoring' also includes the international outsourcing, namely the propensity to import intermediate inputs for production from foreign suppliers at arm's length (OECD, 2008, p. 17).
} 
In this context, traditional horizontal market-seeking FDIs have ever since combined with vertical efficiency-seeking cross-border fabrication activities, leveraging on the relative abundance of low-wage, de-unionised workers, mostly located in emerging and developing countries (Dachs et al., 2012, 2015; Siedschlag et al., 2013). ${ }^{2}$

Nonetheless, in last decades the internationalization of manufacturing activities has proceeded hand in hand with a move towards the globalization of R\&D by large MNCs. Consistently, since the 1980s several authors have emphasized the emergence of global innovation networks, wherein MNCs and their affiliates are key players in the cross-border development, absorption, and transfer of knowledge (Behrman \& Fischer, 1980a, b; Cantwell, 1995; De Beule \& Van Beveren, 2019; De Prato \& Nepelski, 2014; Phene \& Tallman, 2018; Sachwald, 2008; UNCTAD, 2005). ${ }^{3}$ In this regard, several studies have stressed that cross-border investment in the most knowledge-intensive activities, especially R\&D and design, broadly present an efficiency-oriented or learning-oriented nature (Dunning, 1993; Narula \& Zanfei, 2005; Papanastassiou et al., 2020). Efficiency-seeking FDIs include home-base-exploiting and market-seeking R\&D. The former are aimed at taking benefit from the firm-specific technological advantages in a foreign country whose technological capabilities are weak in the considered field. The latter are prompted by the MNCs' need of adapting and customizing domestically originated goods to host country requirements, and of intercepting a potential growing demand coming from large foreign markets. These motivations largely reflect the traditional view of MNCs as endowed with superior technology and capacities to exploit the knowledge assets they are equipped with (Kindleberger, 1969; Stopford \& Wells, 1972; Vernon, 1966, 1979).

In addition to this capability-exploiting determinants of the internationalization of R\&D, an increasing attention has been devoted to MNCs' efforts for augmenting the knowledge base of the domestic production and taking advantage of technological spillovers. In this context MNC subsidiaries play a key role in knowledge absorption and competence creation (Álvarez \& Cantwell, 2011; Cantwell \& Mudambi, 2005). MNCs are thus able to tap into the host country's pool of knowledge, promoting asset-seeking and asset-augmenting strategies, expanding their global innovation network and strengthening their technological capabilities in the long run (Blanc \& Sierra, 1999; Cantwell \& Piscitello, 2000; Dunning \& Narula, 1995; Le Bas \& Sierra, 2002; Pearce, 1999; Pearce \& Papanastassiou, 1999; Siedschlag et al., 2013; Zanfei, 2000).

As regards the regions of origin of foreign affiliates, it is widely acknowledged that MNCs based in Europe and North America have long represented the most important actors in the global economic landscape. After the Second World War US-owned MNCs experienced a rapid growth and a remarkable leapfrog in their international scope. As witnessed by the editorial success of a book by an influential French journalist—which allegedly summarizes the spirit of that age -, in Europe this phenomenon raised fears related to the so-called "American challenge", with specific reference to the growing penetration of US MNCs' affiliates in Europe (Servan-Schreiber, 1968). Moreover, the

\footnotetext{
2 This emphasis on the role of MNCs as actors with a superior capacity to combine and leverage upon lowcost production factors available across national borders is largely consistent with the traditional views of "asset-exploiting" FDIs, as opposed to the relatively rarer "asset-seeking" strategies (Dunning 1993). While this distinction applies to FDIs in all business activities, it is mainly associated with R\&D FDIs, which have historically proceeded at a lower pace and intensity than FDIs in fabrication activities.

3 Papanastassiou et al. (2020) offer a comprehensive and updated literature review on the internationalization of innovation and the role of MNCs in this respect. See also Castellani (2018) for an overview about the MNCs-driven developments in the geography of innovation.
} 
author argued that the power of North American subsidiaries was mainly due to less constrained financial conditions and especially to a 'management gap' between US and European firms in favour of the former, predicting a potential American monopoly on know-how and technological progress. Few years later, Franko (1976) came to downsize the arguments advanced by Servan-Schreiber, stressing that European MNCs enjoy a greater experience in international management given their earlier appearance in the international arena, and that even in the 1970s their affiliates-although fewer than US MNCs'-were growing faster.

A noteworthy perspective was advanced by Hymer and Rowthorn (1970), whoaddressing the debate sparked by Servan-Schreiber (1968) - argued that MNCs based in different home regions would tend to converge in their geographic patterns of FDI because of increasing oligopolistic rivalry for control of strategic market outlets. Accordingly, the authors even predicted that "in the coming competition between European and U.S. corporations, the markets of the third world will be an important battleground" (Hymer \& Rowthorn, 1970, p. 91).

While Hymer and Rowthorn have the merit of drawing the attention of scholars to the interdependencies of US and European MNCs in the race for long run competitiveness, their view clearly reflects international investment patterns of the time, with scarce perception of the increasing fragmentation of production and of the growing role played by emerging countries in the world scenario. Some more recent studies have in fact provided no support to their prediction, showing a lack of convergence in the internationalization strategies of MNCs of different nationalities (Belderbos et al., 2013; Cantwell, 1995; Cantwell \& Janne, 1999; Edler, 2008; Patel, 2011; Sachwald, 2008). In this context, several studies used patent data to investigate the propensity of some of the largest European MNCs to globalize their technological activity in the US and vice-versa, finding that the former tend on average to be considerably more internationalized than US firms (Cantwell \& Janne, 2000; see also Cantwell et al., 2002, 2004).

Moreover, the entry of fast-growing emerging countries in the world market, notably China and India, has deeply affected the race for long run competitiveness among key world actors. In fact, the Asian continent plays an increasingly important role as a hub for the location of both manufacturing and R\&D-intensive facilities by mainly European and US MNCs (Athukorala \& Kohpaiboon, 2010; Chen, 2008; Ernst, 2006; Reddy, 1997, 2011; von Zedtwitz, 2004; von Zedtwitz \& Gassmann, 2016; Zhang \& Pearce, 2010). Some evidence in this respect is provided by Laurens et al. (2015), who use data on 946 large firms which applied for at least five priority patents in both 1994-1996 and 2003-2005 periods and investigate the degree of internationalization as the share of corporate patents with inventors located outside of the country of the firm headquarters (using the inventor's country of residence as a proxy for the location where the technological activity related to the invention occurred). They find that (i) the internationalization of $R \& D$ is much larger for Europe than for the US over both periods considered, although the former decreased while the latter considerably increased with respect to mid-90 s; (ii) notably, the patenting effort of US firms in Asia is twice as high as for European firms, and the share of international patents of US firms with Asian inventors is nearly four times that of European firms; (iii) US firms show by far the highest rate of home-base-augmenting motivations underpinning their rationale for R\&D internationalization compared to European firms, which conversely are more driven by home-base-exploiting motivations in both periods considered.

Furthermore, by using OECD, Eurostat, and National Statistics data on inward and outward Business Enterprise R\&D (BERD) as proxies of R\&D internationalization, Dachs et al. (2014) show that the US hold the lion's share of overseas R\&D expenditure, most of 
which is undertaken within the EU. While little evidence is provided on BERD carried out by US and EU firms in emerging countries due to data limitations, these authors also find that the largest fraction of inward BERD in China is accounted for by US companies.

As the findings of the empirical research we have briefly recalled rely on patent data and official statistics on business enterprise R\&D expenditure, they can only indirectly capture innovation flows associated to cross-border investment patterns. ${ }^{4}$ Nevertheless, they do suggest a stronger propensity of US firms to involve emerging economies, especially Asian countries, in their global innovation networks compared to their European counterparts, further contradicting the conjecture formerly advanced by Hymer and Rowthorn (1970).

When it comes to FDIs undertaken by MNCs based in different advanced regions, little attention has been paid to diverging investment strategies across value chain activities. Few partial exceptions are represented by works in which, however, such patterns are examined from a rather short-term perspective and mostly with a focus on R\&D FDIs only (Belderbos et al., 2016; Huggins et al., 2007; OECD, 2008). In this context, Belderbos et al. (2016) use fDi Markets data from 2003 to 2011 and note only in passing that US firms promoted in absolute terms more FDIs in R\&D and Design Development and Testing (DDT) towards the Asian countries than EU firms.

Still, what remains to be explored is how these leading regions differ in terms of geographical distribution of outward FDIs related to R\&D and other functions of the global value chain (GVC). This also relates to a growing body of literature which has shown that cross-border investment flows are a major driver of the international fragmentation of value chains at the level of individual production stages - from the R\&D activities related to the conception of products to their fabrication stages, up to their commercialization and distribution (Feenstra, 1998; Mudambi, 2008; Sturgeon \& Gereffi, 2009; Bernard et al., 2017; UNCTAD, 2013). This literature also stressed how such a fragmentation of production has entailed an increasing involvement of low- and middle-income countries in GVCs, enacting different mechanisms of knowledge transfer between leading multinationals and local subcontractors (Gereffi et al., 2005; Saliola \& Zanfei, 2009).

Accordingly, in what follows we take full advantage of the richness of the fDi Markets database to investigate the global patterns of outward FDIs in knowledge-intensive compared to manufacturing activities assuming a comparative perspective. The aim is to provide an answer to the following research questions:

(i) How do North American and European FDI patterns differ across destination regions, with special reference to their propensity to invest in emerging economies?

(ii) How do European and North American FDIs towards emerging regions differ across value chain activities, with special reference to knowledge-intensive and manufacturing activities?

Addressing these questions is crucial to assess the different investment strategies pursued by European and North American MNCs on a global scale and to detect convergent and divergent patterns in their evolution. Furthermore, the analysis of FDI decisions of these major players and the different role of emerging countries, both as destination of investment flows and as new competitors in global markets, can provide fruitful insights on

\footnotetext{
${ }^{4}$ In fact, the data used in these studies do not allow a distinction of the ownership structure of the investors (in the case of BERD) or of the applicant (in the case of patents) hence making it impossible to distinguish whether the innovation inputs or outputs are associated with multinationals and their cross-border activities.
} 
the long-term competitiveness of MNCs based in the economies which have hitherto dominated the global knowledge hierarchy.

\section{Data}

\subsection{The fDi markets database}

The empirical analysis performed in the present work relies on fDi Markets, an online database provided by fDi Intelligence - a specialist division of Financial Times Ltd-which monitors cross-border investments covering all sectors and countries worldwide from 2003 onwards. The database represents one of the main data sources in UNCTAD's World Investment Report (notably, fDi Markets is the only source on greenfield FDIs used by UNCTAD) and has been exploited in publications by the Economist Intelligence Unit.

fDi Markets is an event-based (or deal-based) database, i.e., each entry is a project, which collects detailed information on announced cross-border greenfield investments (i.e., new wholly owned subsidiaries, including joint ventures whether they lead to a new physical operation) from several publicly available information sources. The latter include nearly 9000 media sources, over 1000 industry organizations and investment agencies, and data purchased from market research and publication companies. The detected projects are cross-referenced against a plurality of sources and over $90 \%$ of projects are validated with company sources (Castellani \& Pieri, 2013; Castellani et al., 2013). ${ }^{5}$

fDi Markets reports information related to the geographical dimension and type of investment, including the "cluster" (aggregate of industries), industry and subsector the investment is directed to, as well as information on the main business activity involved in the project. The classification of business activities associated to investment projects is a distinctive characteristic of the database and constitutes the key information which allows us to compare FDI patterns in distinct stages of the GVC.

In addition, fDi Markets reports the date of the project, the amount of capital invested in monetary terms and the number of jobs created by the investment, although the latter two information refers, almost exclusively, to estimated values. As criteria for value estimation are not made explicit, we perform our investigation mostly relying on the number of FDI projects rather than on the value of capital involved. Furthermore, since we focus on the global patterns of FDIs highlighting their locational patterns, we follow Crescenzi et al., (2015, p. 33) holding that often the number of investment decisions in a given geographical destination is likely to be a more proper unit of analysis than the value of the project insofar as such decisions have been demonstrated to be broadly independent from the amount of capital invested (Amighini et al., 2014; Sutherland \& Anderson, 2014). Consistently, several empirical works using fDi

\footnotetext{
${ }^{5}$ In order to check the reliability of the distribution of the number of investment projects included in fDi Markets, Castellani and Pieri (2013, p. 1592) computed the Pearson correlation coefficient between the distribution of inward and outward FDIs by EU countries provided by fDi Markets and the one of FDI flows as reported by UNCTAD over the period 2003-2006 and found a correlation coefficient higher than 0.80 . In another work, the same authors (Castellani \& Pieri, 2015, p. 6) found a correlation coefficient closer to 0.90 over the period 2003-2007. A similar robustness check at country level has been performed by Crescenzi et al., (2014, p. 1065), which found a correlation of 0.54 over the period 2003-2008. These authors also computed the correlation in the number of investments in Europe at the NUTS2 level recorded by fDi Markets and the Euromonitor database (which provides information on FDI flows in Europe based on a completely independent source) and found that it is equal to 0.75. See also Ascani et al. (2016).
} 
Markets have been performed exploiting the number of FDI projects rather than the data on capital investment (Castellani \& Pieri, 2013, 2015; Castellani et al., 2013, 2016; Crescenzi et al., 2014, 2015; Ramasamy et al., 2012). Nevertheless, given that this choice involves disregarding the scale of investments and might bias our results, we report the most meaningful descriptive statistics also using data on capital investment. In this way, we can assess the size of investment projects according to different geographical and industrial dimensions, while checking the consistency of computed indicators with the ones based on the number of FDIs.

One shortcoming of the fDi Markets database is that it is based on planned future investment projects as reported by press and other specialized information sources. It follows that some of these projects might not be carried out or may be realized in a form which differs from the one reported by the database. Even though the database is daily updated and projects which have not been successful are periodically deleted from the database, this data-collection method may determine some inaccuracies. This problem might occur especially in the case of most recent events which are less likely to have undergone cross-referencing and reliability checks. Although we have access to the data from 2003 to 2018, we thus chose not to consider the FDI projects recorded during the last available year, limiting our analysis to the time span 2003-2017 and thus improving the reliability of our results. During this period, fDi Markets includes almost 190,000 investment projects worldwide carried out by about 73,000 investing companies controlled by more than 53,000 parent companies.

Another limitation of fDi Markets concerns the inclusion of greenfield investments only (as well as major extensions of existing projects), whereas it does not cover information on mergers and acquisitions (M\&As). While focusing on greenfield investments allows to capture the majority of FDI flows (UNCTAD, 2013, 2020), not considering M\&A might introduce a downward bias in the evaluation of inward investments especially in advanced economies, as brownfield investments are the more likely to occur the greater the business opportunities offered by the host economy. Similarly, considering only greenfield investments might lead to underestimate cherry-picking FDIs which are most significant in dynamic markets. Since we are interested in comparing FDI trajectories from Europe and North America (both advanced economies) towards emerging and developing countries, not considering brownfield investments might be less of a problem, as cherry-picking and financial motivations apply much less in these countries. This encourages us to proceed with our analysis while acknowledging the limitations mentioned above.

\subsection{Global patterns of knowledge FDIs}

As mentioned earlier, one of the most important features of FDIs Markets is that it allows to distinguish foreign investments according to the value chain functions performed by assigning each project to the business activity it refers to. The activities included in the database span from headquarters to research \& development (R\&D), design, development and testing (DDT), extraction, manufacturing, retail, etc. ${ }^{6}$ In particular, R\&D activity is defined as "the discovery, design, or development of a product" which includes "pure research" and represents the most upstream function in the value chain being the most science-intensive type of research. DDT activity involves "designing, developing or testing a

\footnotetext{
6 The complete list of business activities classified by fDi Markets, together with an exhaustive description and their evolution over time in terms of number of FDIs, is reported by Zanfei et al. (2019).
} 
product", mainly encompassing applied research and thus being closer to the commercialization of innovation.

Due to our focus on investment strategies related to the internationalization of knowledge, we choose to concentrate our attention on R\&D and DDT activities, while comparing them with foreign investment patterns in the manufacturing function. The latter are the most relevant component of the globalization of production, covering one fourth of worldwide FDIs over the period, and $40 \%$ of them in terms of capital invested. Conversely, R\&D and DDT investment projects amount to about $7 \%$ of total FDIs over the entire period, with $R \& D$ representing the smallest share with less than $2 \%$ of the 188,000 investment projects registered in the dataset. The global patterns of these high value-added activities located upstream of the value chain are shown by Fig. 1, which provides an imagine of the growing globalization of innovation and knowledge over the last two decades. The first noteworthy element is the sharp decrease in FDIs related to R\&D activity after 2007, i.e., in correspondence with the outbreak of the global financial crisis. Such a collapse is counterbalanced by a remarkable rise of FDIs in Design, Development and Testing activities over the whole period, resulting in an increasing gap between the patterns of R\&D- and DDT-related investment flows. ${ }^{7}$

\section{A comparative analysis of foreign investment decisions}

\subsection{European and North American FDIs across value chain activities}

Table 1 shows the share of outward FDIs originating from Europe and from North American countries in R\&D and DDT activity on the one side, and in manufacturing activity on the other side, over the whole period under investigation. ${ }^{8}$ As expected, Europe and North America hold the lion's share of world outward FDIs: over 70\% of total gross outward FDI flows originate from these areas of the world, although they together represent one third of world GDP and little more than one tenth of world population in 2017 (IMF, 2019). ${ }^{9}$ This share is even higher when it comes to knowledge offshoring: Europe and North America originate about $80 \%$ of total FDIs in R\&D and DDT, while the rest of world-representing $66 \%$ of world GDP - only promotes the remaining $20 \%$ of the overall 12,491 knowledge FDIs.

However, remarkable differences can be observed between the two leading areas of the world when it comes to the composition of investment flows. First, net of intraregion FDIs, Europe's share of world cross-border investments in manufacturing activities $(29.6 \%)$ is higher than its share of world FDIs in technological activities (24.2\%). The

\footnotetext{
7 These patterns are substantially confirmed by data in terms of capital invested, the main difference being that capital invested of FDIs in R\&D activity was higher than capital invested of FDIs in DDT until 2005; see Fig. 1 in the Online Appendix.

8 The EU28 + country group is composed by the EU28 countries to which we added Norway and Switzerland, a choice dictated by the economic sense as their GDP per capita is comparable to the countries included in the EU28 group. North American region includes United States and Canada.

9 Even excluding intra-regional FDIs, Europe and North America still account for about $51 \%$ of total investment projects over the whole period. More generally, advanced economies all together promoted $84 \%$ of total number of projects over the period. This evidence is substantially confirmed by data on capital investment, which shows that advanced economies covered nearly $80 \%$ of outward FDIs (see also Zanfei et al., 2019).
} 


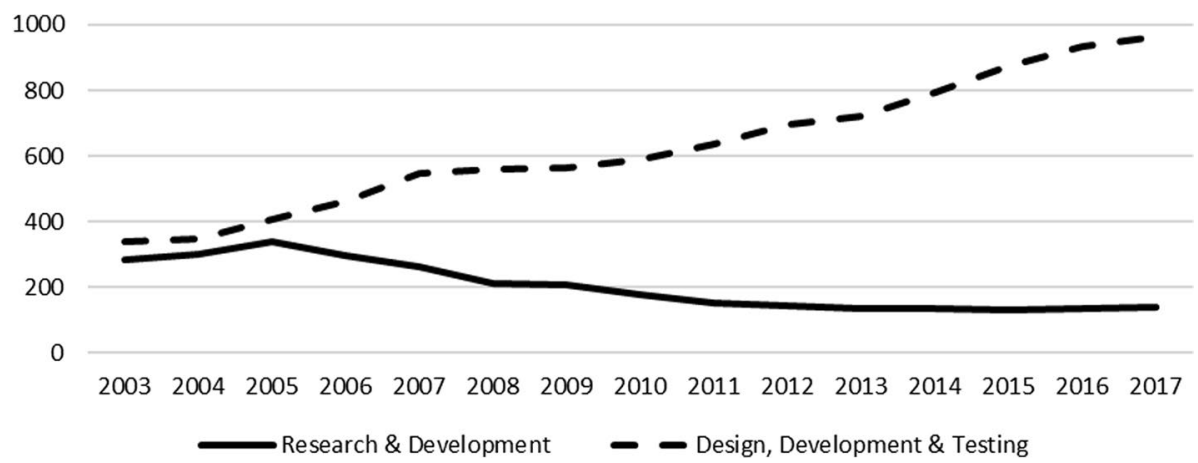

Fig. 1 Number of FDIs in technological activities, 3-year moving average, 2003-2017. Source: Authors' elaboration on fDi Markets database

Table 1 Share of world outward FDIs (computed on number of FDI projects) in technological and manufacturing activities (\% by region of origin), 2003-2017

\begin{tabular}{llllll}
\hline Region of origin & $\begin{array}{l}\text { R\&D and } \\
\text { DDT activ- } \\
\text { ity }\end{array}$ & $\begin{array}{l}\text { Manu- } \\
\text { facturing } \\
\text { activity }\end{array}$ & Total & $\begin{array}{l}\text { Share of world } \\
\text { GDP in 2017 }\end{array}$ & $\begin{array}{l}\text { Share of world } \\
\text { population in } \\
2017\end{array}$ \\
\hline EU28+(net of intra-region FDIs) & 24.2 & 29.6 & 27.2 & 17.2 & 7.1 \\
EU28+'s intra-region FDIs & 13.3 & 15.6 & 18.6 & & \\
North America (net of intra-region & 40.1 & 17.8 & 24.1 & 16.7 & 4.9 \\
$\quad$ FDIs) & & & & & \\
North America's intra-region FDIs & 2.0 & 1.7 & 1.9 & & 88.0 \\
Rest of World & 20.4 & 35.3 & 28.2 & 66.1 & 100 \\
Total & 100 & 100 & 100 & 100 & \\
Total number of FDIs & 12,491 & 45,927 & 187,946 & & \\
\hline
\end{tabular}

Source: Authors' elaboration on fDi Markets database and IMF data

Table 2 Share of outward FDIs (computed on number of FDI projects) in technological and manufacturing activities by Europe and North America towards Advanced and Emerging economies (\% by destination region), 2003-2017

\begin{tabular}{|c|c|c|c|c|c|c|}
\hline \multirow[t]{3}{*}{ Destination regions } & \multicolumn{6}{|l|}{ Source regions } \\
\hline & \multicolumn{3}{|l|}{ EU28+ } & \multicolumn{3}{|l|}{ North America } \\
\hline & R\&D and DDT & Manufacturing & Total & R\&D and DDT & Manufacturing & Total \\
\hline Advanced economies & 52.8 & 34.5 & 49.8 & 44.3 & 35.5 & 50.9 \\
\hline Emerging economies & 47.2 & 65.5 & 50.2 & 55.7 & 64.5 & 49.1 \\
\hline World & 100 & 100 & 100 & 100 & 100 & 100 \\
\hline Abs. number of FDIs & 4684 & 21,220 & 86,063 & 5261 & 8934 & 48,843 \\
\hline
\end{tabular}

Source: Authors' elaboration on fDi Markets database 
opposite applies to North America whose share of world R\&D and DDT FDIs is much higher $(40.1 \%)$ than its share of manufacturing FDIs (17.8\%). ${ }^{10}$

Second, the lower (higher) propensity of European (North American) economies to promote outward FDIs in technological activities can also be observed by means of a comparison with their share of total outward FDIs. In fact, the European share of outward FDIs in technological activities (24.2\%) is lower than its overall share of total FDIs (27.2\%); while - quite symmetrically - the European share of FDIs in manufacturing (29.6\%) is larger than its overall share of world FDIs. Once again, the opposite can be observed in the case of North American economies, whose share of FDIs in technological activities $(40.1 \%)$ is much higher than their share of overall outward FDIs $(24.1 \%) .{ }^{11}$ Using standard Balassa indexes, Europe thus exhibits an outward FDI-based specialization lower than one (0.89) in R\&D and DDT activities and higher than one (1.09) in manufacturing activity, showing a relatively higher propensity to cross-border investments of the latter type. On the opposite, North America shows a strong Balassa-like specialization in knowledgeintensive activities (equal to 1.66) while for manufacturing activity exhibits a value lower than one (equal to 0.74). Our evidence therefore confirms with a richer set of data and with reference to a longer time span what received only a passing consideration in earlier studies reviewed in Sect. 2: North America exhibits a much higher propensity to globally disperse R\&D labs with respect to Europe.

Table 2 provides a further element of analysis, namely the macro-regions of destination of global investments originating from Europe and North America. Destination regions are divided into two broad groups of countries, i.e., the advanced and the emerging ones. ${ }^{12}$

Both North American and European regions direct about two thirds of their cross-border investment flows in manufacturing activities towards the emerging economies. ${ }^{13}$ Broadly speaking, the two largest and most advanced areas thus confirm their propensity to carry out a substantial part of their manufacturing activities in less developed, lower cost, albeit emerging regions of the world.

However, a major difference emerges when looking at the offshoring of technological activities. While Europe distributes most of its R\&D and DDT FDIs towards advanced economies, North America shows a much stronger projection towards emerging economies in upstream, knowledge-intensive, stages of the value chain. In fact, 55.7\% of technological

\footnotetext{
10 As shown in Table 2, the total number of FDI projects promoted by Europe $(86,063)$ is about $75 \%$ higher than investments outgoing from North America $(48,843)$. Europe originates more than twice as many manufacturing FDIs as North America $(21,220$ vs. 8,934). The opposite applies when looking at the knowledgeintensive flows of investment: the absolute number of FDIs in technological activities from North America $(5,261)$ turns out to be higher than Europe's $(4,684)$.

11 These results are substantially confirmed by data in terms of capital invested; see Table 1 in the Online Appendix.

12 Advanced economies include the following groups of countries: EU15, Cyprus, Malta, Norway, Switzerland, North America (i.e., United States and Canada), Japan, the Four Asian Tigers (Hong Kong, Singapore, South Korea, and Taiwan), and Australia \& New Zealand. Emerging economies are grouped as follows: Central and Eastern European countries (CEECs)_including Bulgaria, Croatia, Czech Republic, Estonia, Hungary, Latvia, Lithuania, Poland, Slovakia, Slovenia and Romania -, Non-EU Europe, Russia, China, India, the Rest of Asia, the Middle East \& North Africa, Sub-Saharan Africa and Latin America.

13 As already mentioned in Sect. 3, the fDi Markets database on which this analysis relies on includes greenfield investments only, not covering information on M\&As. This circumstance is likely to account for the discrepancy between our data and other official statistics on the patterns of global investment flows (UNCTAD, 2020). See Sect. 3 of the present work for further discussion.
} 
FDIs from the North American region were directed towards emerging countries, a share remarkably higher than the one related to its total FDI projects $(49.1 \%){ }^{14}$

These differences in patterns of FDIs along the value chain is largely driven by the US in the North American region and by a few core EU member states in the European continent. This is shown in Table 3, which reports the distribution of outward FDI projects by individual country of origin. Within the European region, Germany, UK and France are the most important investors, overall accounting for $51 \%$ of total FDI projects, $48 \%$ of total FDIs in manufacturing and 58\% of FDIs in technological activities (Panel a). Looking at the data on FDIs which target emerging economies, reported by (Panel b) of Table 3, the hierarchy is substantially confirmed: Germany, UK and France cover 50\% of overall FDIs, $48 \%$ of FDIs in manufacturing and $60 \%$ of FDI projects in technological activities. Both these patterns are confirmed by data on capital invested (see Table 3 in the Online Appendix). Within the North American region, United States account for the very largest share of FDIs overall and especially regarding the ones in R\&D and DDT activities, both with reference to the number of FDIs and the capital invested.

Most notably, a few countries originate most of FDIs in knowledge-intensive activities, while a higher dispersion is recorded when looking at home countries of FDIs in manufacturing activity. As shown in Table 3, the top 5 countries hold $75 \%$ of European FDIs in R\&D and DDT, while the same countries control slightly more than $60 \%$ of manufacturing FDIs. In a similar vein, the US is responsible of $95.1 \%$ of North American investments in technological activities and of $87.3 \%$ of FDIs in manufacturing. The dominating role of the US in knowledge-intensive FDIs is even more apparent when emerging countries are considered as a destination: the US share is even higher (96.6\%) when accounting for R\&D and DDT FDIs from North America towards the South of the world only.

\subsection{European and North American FDIs towards economic sub-regions}

Figures 2, 3 and 4 unpack investment outflows by sub-regions of destination. Figure 2 reports the share of total FDIs towards selected emerging regions (to which we add the Four Asian Tigers as a fast-growing technology-oriented region) out of the total cross-border investment flows originating from Europe and North America; Figs. 3 and 4 follow the same scheme but for manufacturing and knowledge-intensive FDI projects, respectively.

Figure 2 shows the stronger projection of the North American region towards fast growing emerging economies-especially the Asian ones-with respect to Europe. North America promoted 10, 8 and 7\% of its total FDIs towards China, India, and the Four Asian Tigers, respectively; Europe invested the $6.6 \%$ out of its overall cross-border investments in China, and just $4.5 \%$ and $4 \%$ towards India and the Four Asian Tigers, respectively. It thus appears that the propensity of North American MNCs to invest in the most dynamic emerging countries is disproportionally higher than observed in the case of European MNCs. ${ }^{15}$ As expected, European countries exhibit a much stronger projection towards Central and Eastern European countries (CEECs) (11.7\% out of total FDIs from Europe, equal

\footnotetext{
14 These results are substantially confirmed by data in terms of capital invested; see Table 2 in the Online Appendix.

15 In absolute terms, Europe is the main investor, but remarkably less so if FDIs towards emerging countries are considered. In fact, while total FDIs originating from Europe (86,063 investment projects) are almost twice as many as those originating from North America (48,843 projects), the amount of European investments is only slightly higher than North American ones, when the FDI targeting emerging countries are considered (13,167 vs. 12,109 projects respectively).
} 
to 10,080 projects) while North America confirms its vigorous presence in Latin American economies (11\% of its total FDIs, equal to 5,323 projects). Less dynamic areas, as Middle East \& North Africa, Sub-Saharan Africa, Non-EU European economies, and Russia received a much lower amount of cross-border investment from both Europe and North America. ${ }^{16}$

Figure 3 reports the share of manufacturing FDIs out of world cross-border investment projects promoted by European and North American countries, respectively. Remarkable differences emerge here too. First, China appears to have drawn a much greater amount of manufacturing foreign investments from North America than from Europe. Indeed, both advanced regions of the world appear to have invested a lot in China, but North America promoted $16 \%$ of its total manufacturing FDIs towards this country (1,442 projects), while Europe has directed there a much lower share of its manufacturing investments $(10.6 \%$ corresponding to 2,259 projects). These shares are higher than those calculated on total FDIs (Fig. 2), confirming the role of China as the single most important "world's factory" for advanced economies. By contrast, the shares of manufacturing FDI deals Europe and North America promoted in the Four Asian Tigers and especially in India turns out much lower than in the case of China, signaling their relative specialization in attracting FDIs related to other activities of the value chain (mostly high value-added functions associated to software and ICTs). Second, apart from Asian locations, European and North American MNCs rely on distinctive "manufacturing hubs", with the former localizing a substantial share of FDI in CEECs and the latter in Latina America. Each of these leading regions invested about $18 \%$ of their cross-border investments towards these relatively close-by regions, which end up acting as "back-yard factories" for the most advanced areas of the world. ${ }^{17}$

The different global investment strategies pursued by the European and the North American regions are particularly apparent when it comes to FDIs in technological activities (Fig. 4). The propensity of North American MNCs to invest in the most dynamic emerging countries is even stronger in the case of R\&D and DDT. This is particularly the case of China and, even more so, the case of India. In fact, the share of FDIs in technological activities of North American countries towards China (13.1\%, equal to 687 projects) is about $25 \%$ higher than in the case of European investments towards the same country $(10.6 \%$, equal to 497 projects). Even more remarkable, the share of FDIs in technological activities of North American economies towards India is very high (21.7\%, equal to 1,140 projects) and it is twice as high as the one of European economies (10.7\%, equal to 499 projects).

To be clear, a large fraction of advanced economies' FDIs in technological activities do flow towards the advanced countries themselves, with Europe being the largest single recipient region (33\% of world FDIs in technological activities are directed towards Europe, against $12 \%$ drawn by North America). Nonetheless, the majority of North American FDIs in technological activities targeted emerging economies. Notably, China and India together attract over one third (35\%) of North America's outward FDIs in technological activities, while the share of European outward FDIs in technological activities targeting the two Asian giants is much lower, amounting to a total of $21.3 \%$. Correspondingly, North American investments represent

\footnotetext{
16 These results are largely confirmed by data in terms of capital invested; see Fig. 2 in the Online Appendix.

17 These results are substantially confirmed by data in terms of capital invested (see Fig. 3 in the Online Appendix), the main differences being that, on the one side, European and North American economies targeted roughly with the same intensity China for the manufacturing stages of production (with North America still presenting a little positive gap with respect to Europe); on the other side, from the figure emerges a slightly stronger projection of North America and Europe towards Middle East \& North Africa and Russia, respectively.
} 
Table 3 Share of outward FDIs (in terms of number of FDI projects) in technological and manufacturing activities towards World economies (Panel a), and towards Emerging economies (EEs) (Panel b), \% by country of origin, 2003-2017

\begin{tabular}{|c|c|c|c|}
\hline \multirow[t]{2}{*}{ Source country } & \multicolumn{3}{|l|}{ Activity } \\
\hline & $\mathrm{R} \& \mathrm{D}$ and DDT & Manufacturing & Total \\
\hline \multicolumn{4}{|c|}{ (Panel a) FDIs towards world } \\
\hline Germany & 26.7 & 27.0 & 19.6 \\
\hline UK & 17.5 & 9.7 & 19.9 \\
\hline France & 14.2 & 11.6 & 11.6 \\
\hline Switzerland & 10.3 & 8.0 & 7.4 \\
\hline Netherlands & 6.3 & 5.6 & 6.0 \\
\hline Sweden & 4.7 & 4.3 & 4.1 \\
\hline Finland & 2.9 & 3.3 & 2.4 \\
\hline Ireland & 2.7 & 1.2 & 2.4 \\
\hline Spain & 2.5 & 4.9 & 6.1 \\
\hline Denmark & 2.4 & 2.9 & 2.5 \\
\hline Belgium & 2.2 & 2.8 & 2.3 \\
\hline Italy & 2.1 & 7.3 & 4.4 \\
\hline Norway & 1.5 & 1.6 & 1.7 \\
\hline Austria & 1.3 & 4.2 & 3.2 \\
\hline Luxembourg & 1.3 & 1.5 & 1.3 \\
\hline Poland & 0.3 & 0.6 & 0.6 \\
\hline Czech Republic & 0.2 & 0.5 & 0.6 \\
\hline Portugal & 0.2 & 0.8 & 0.9 \\
\hline Greece & 0.1 & 0.7 & 0.5 \\
\hline Cyprus & 0.1 & 0.2 & 0.4 \\
\hline Estonia & 0.1 & 0.1 & 0.3 \\
\hline Hungary & 0.1 & 0.3 & 0.3 \\
\hline Bulgaria & 0.1 & 0.2 & 0.1 \\
\hline Croatia & 0.1 & 0.2 & 0.1 \\
\hline Malta & 0.1 & 0.0 & 0.1 \\
\hline Lithuania & 0.0 & 0.1 & 0.2 \\
\hline Romania & 0.0 & 0.1 & 0.2 \\
\hline Slovakia & 0.0 & 0.1 & 0.1 \\
\hline Slovenia & 0.0 & 0.5 & 0.3 \\
\hline Latvia & 0.0 & 0.1 & 0.2 \\
\hline EU28+ & 100 & 100 & 100 \\
\hline Abs. number & 4684 & 21,220 & 86,063 \\
\hline United States & 95.1 & 87.3 & 89.3 \\
\hline Canada & 4.9 & 12.7 & 10.7 \\
\hline North America & 100 & 100 & 100 \\
\hline Abs. number & 5261 & 8934 & 48,843 \\
\hline
\end{tabular}


Table 3 (continued)

\begin{tabular}{|c|c|c|c|}
\hline \multirow[t]{2}{*}{ Source country } & \multicolumn{3}{|l|}{ Activity } \\
\hline & $\mathrm{R} \& \mathrm{D}$ and DDT & Manufacturing & Total \\
\hline \multicolumn{4}{|c|}{ (Panel b) FDIs towards EEs } \\
\hline Germany & 28.4 & 27.4 & 20.8 \\
\hline UK & 17.7 & 9.1 & 17.6 \\
\hline France & 14.0 & 11.6 & 11.4 \\
\hline Switzerland & 9.4 & 7.0 & 6.2 \\
\hline Netherlands & 5.7 & 5.0 & 5.5 \\
\hline Sweden & 4.8 & 4.2 & 3.8 \\
\hline Finland & 3.6 & 3.5 & 2.7 \\
\hline Spain & 3.2 & 5.6 & 7.4 \\
\hline Denmark & 2.4 & 2.9 & 2.4 \\
\hline Ireland & 1.9 & 0.6 & 1.5 \\
\hline Belgium & 1.9 & 2.5 & 2.2 \\
\hline Italy & 1.9 & 7.8 & 4.9 \\
\hline Norway & 1.4 & 1.3 & 1.5 \\
\hline Luxembourg & 1.0 & 1.3 & 1.4 \\
\hline Austria & 0.9 & 4.6 & 4.2 \\
\hline Cyprus & 0.2 & 0.2 & 0.4 \\
\hline Czech Republic & 0.2 & 0.7 & 0.8 \\
\hline Bulgaria & 0.2 & 0.2 & 0.2 \\
\hline Greece & 0.2 & 0.8 & 0.8 \\
\hline Poland & 0.2 & 0.8 & 0.6 \\
\hline Crotia & 0.1 & 0.3 & 0.2 \\
\hline Estonia & 0.1 & 0.1 & 0.2 \\
\hline Hungary & 0.1 & 0.4 & 0.5 \\
\hline Portugal & 0.1 & 0.8 & 1.1 \\
\hline Slovenia & 0.1 & 0.7 & 0.6 \\
\hline Lithuania & 0.0 & 0.2 & 0.3 \\
\hline Malta & 0.0 & 0.0 & 0.1 \\
\hline Slovakia & 0.0 & 0.1 & 0.1 \\
\hline Latvia & 0.0 & 0.1 & 0.3 \\
\hline Romania & 0.0 & 0.1 & 0.2 \\
\hline EU28+ & 100 & 100 & 100 \\
\hline Abs. number & 2209 & 13,908 & 43,243 \\
\hline United States & 96.6 & 91.6 & 91.3 \\
\hline Canada & 3.4 & 8.4 & 8.7 \\
\hline North America & 100 & 100 & 100 \\
\hline Abs. number & 2928 & 5766 & 23,971 \\
\hline
\end{tabular}

Source: Authors' elaboration on fDi Markets database 


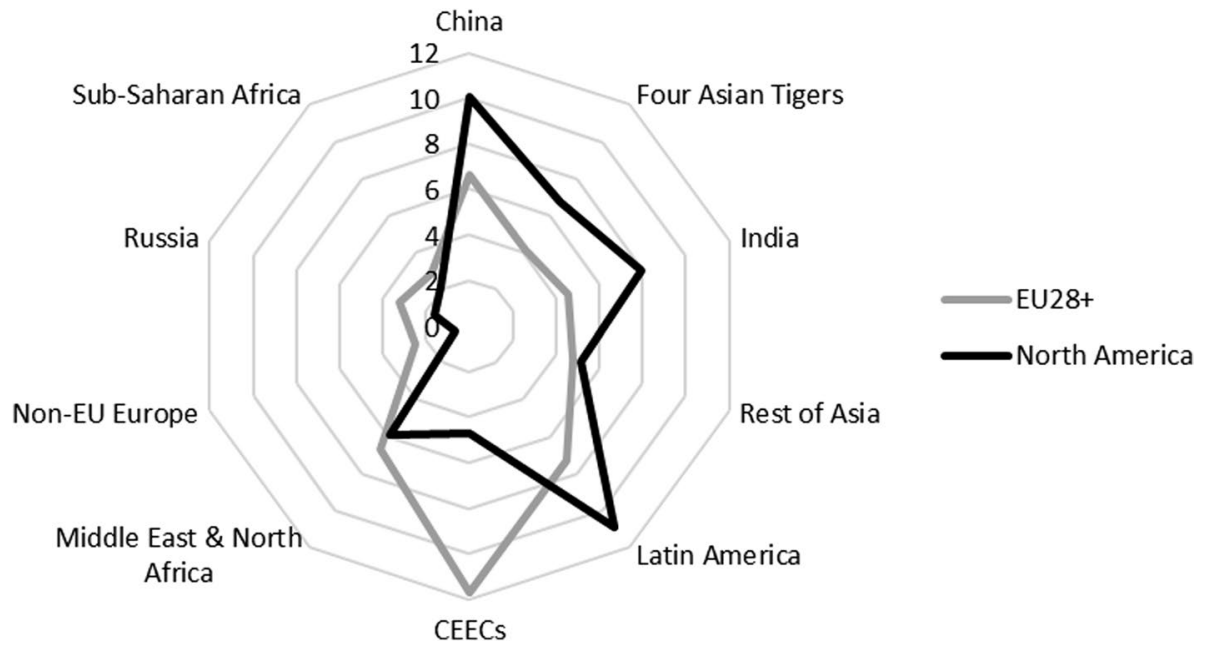

Fig. 2 Share of FDIs towards Emerging economies out of total FDIs from North America and Europea (\% by destination region based on number of FDI projects, 2003-2017). Source: Authors' elaboration on fDi Markets database

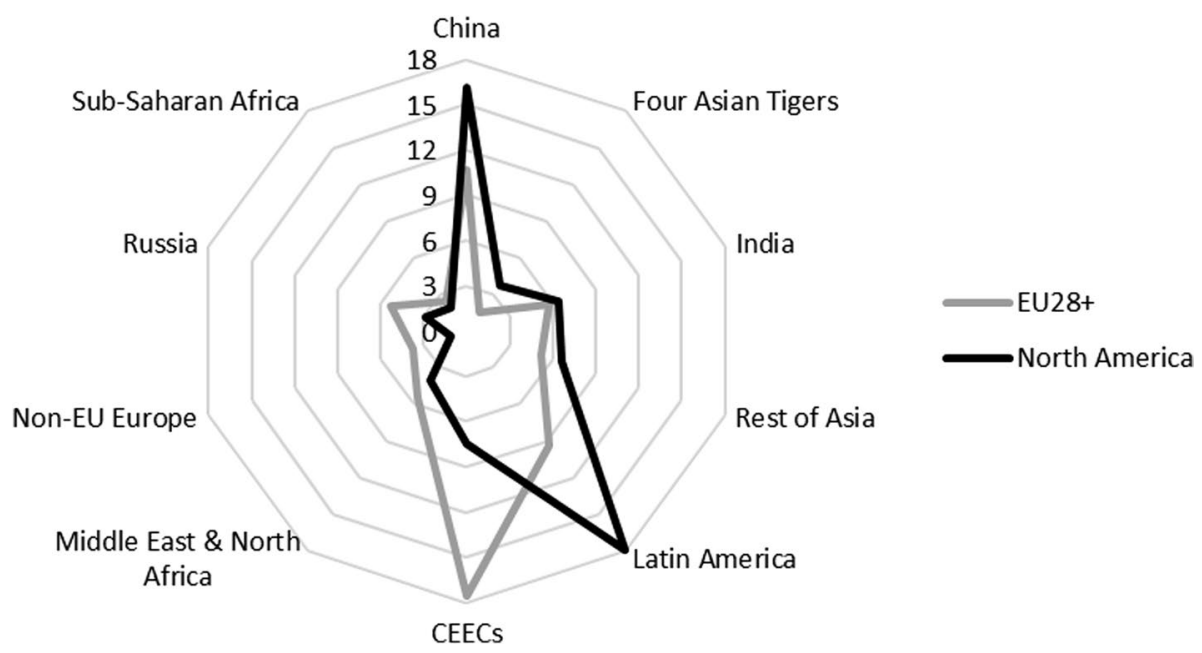

Fig. 3 Share of FDIs towards Emerging economies out of manufacturing FDIs from North America and Europe (\% by destination region based on number of FDI projects, 2003-2017). Source: Authors' elaboration on fDi Markets database 


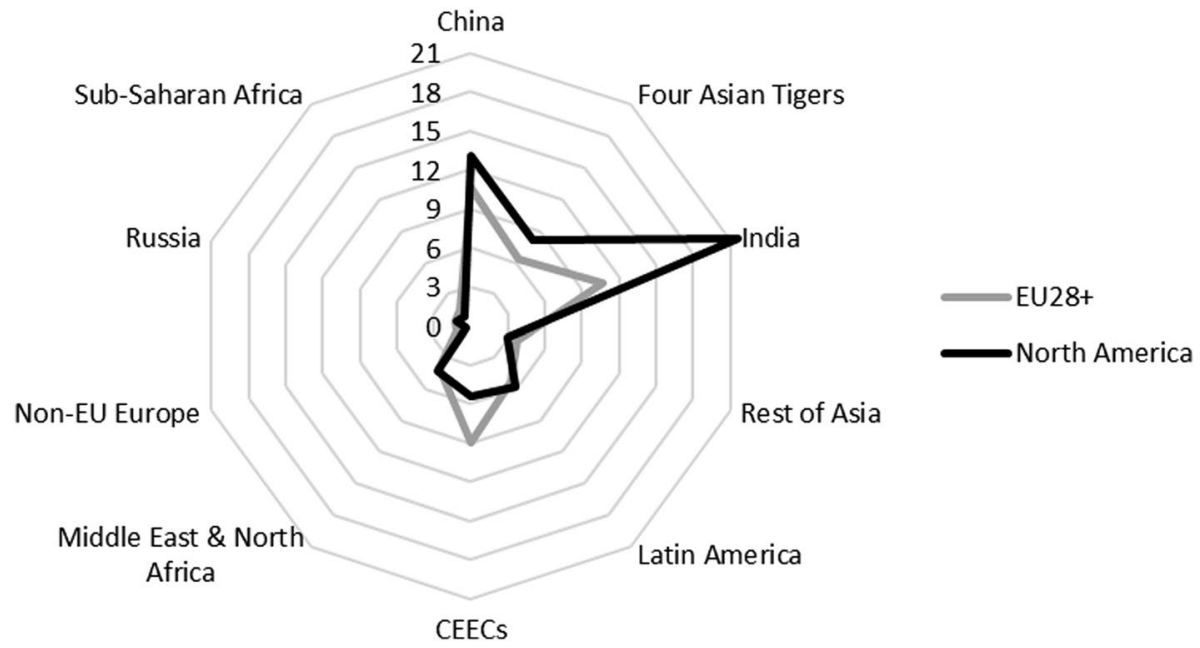

Fig. 4 Share of FDIs towards Emerging economies out of FDIs in $R \& D$ and DDT activities from North America and Europe (\% by destination region based on number of FDI projects, 2003-2017). Source: Authors' elaboration on fDi Markets database

a very important portion of the high value-added FDIs in most emerging countries: they account for $45 \%$ of all FDIs in technological activities accruing to China, $46 \%$ of those towards the Four Asian Tigers, and $61 \%$ of those towards India, while the related shares Europe accounts for these three fast-growing Asian economies are 33, 32 and 27\% respectively.

Consistent with previous observations on FDI patterns towards close-by hubs, European MNCs exhibit a stronger propensity to offshore high value-added functions towards Central and Eastern European countries (9\%) than North America (5.4\%) does, taking advantage of the well-educated low-wage workers located there. Nonetheless, by comparing Figs. 3 and 4, it turns out that CEECs experienced far more relevant inward investment flows in manufacturing activities, reflecting the European MNCs' strategy of delocalizing in those countries the most labour-intensive functions of the value chain (Celi et al., 2018). Moreover, this pattern closely mirrors the global investment trajectory followed by MNCs headquartered in North American economies towards Latin American countries. Thus, while CEECs and Latin American countries may also marginally attract some investments in knowledge-intensive activities, our evidence further confirms that these regions mainly act as "backyard factories" for European and North American MNCs, respectively. ${ }^{18}$

Overall, the geography of cross-border investment flows seems to reflect an international division of labour wherein emerging countries serve as manufacturing hubs for large part of the world. However, this general rule applies much less in the case of North American investors, which appear to involve emerging economies in more knowledge-intensive, higher valueadded activities than investors from other advanced areas do. These findings confirm North America as the leading region in terms of outward FDIs in innovative activities, exhibiting

\footnotetext{
18 These findings are broadly confirmed by data in terms of capital invested; see Fig. 4 in the Online Appendix.
} 
by far the strongest propensity to offshore the most technological (upstream) functions of the value chain into the most dynamic emerging economies, especially China and India.

Finally, there are substantial differences also in the sectoral distribution of European and North American FDIs towards the emerging regions, largely reflecting the specialization of investors. R\&D and manufacturing offshoring to China and India is quite illustrative in this respect. To this regard, Fig. 5 compares the shares of FDI projects in R\&D and DDT activities from European and North American MNCs towards the two Asian giants by industry of destination. Notably, the industries reported in this figure are those attracting the bulk of technological FDIs from the two leading regions we focus on to the Asian countries. As shown, almost 50\% of FDI projects in technological activities from US-based MNCs were in the software and IT services sector, and nearly $10 \%$ in the industry of semiconductors. These shares are respectively from two to three times higher compared to the European ones. Conversely, multinationals from Europe report a higher propensity to offshore the most upstream value chain functions especially in the automotive and industrial machinery and equipment sectors, as well as in chemical and pharmaceutical industries. In particular, the automotive and machinery and equipment sectors drawn about 12 and $9 \%$ of European R\&D-related FDIs towards China and India, respectively, compared to $4 \%$ in both sectors from North America; similarly, European MNCs offshored 11.6 and $6.4 \%$ of their R\&D and DDT activities in chemical and pharmaceutical industries, compared to $4.9 \%$ and $4.2 \%$ from US multinationals.

Figure 6 reports the same comparison regarding manufacturing FDI flows. Both European and North American MNCs offshore the largest share of their manufacturing FDIs towards China and India in the automotive, industrial machinery and equipment, and chemical industries; in particular, these sectors drawn $20 \%$ (14.7\%), 16.3\% (13.1\%) and $15.5 \%$ (14.8\%) of manufacturing FDIs from Europe (North America), with multinationals based in the former region reporting a positive gap with respect to US-based competitors in these industries. Notably, North American MNCs confirm their stronger propensity to invest in semiconductors also when manufacturing investments are at stake; again, the difference in this case is remarkable: while USbased promoted almost $4 \%$ of their manufacturing FDIs in this sector, European MNCs devoted just $0.5 \%$ of their foreign investments in this industry. US-based multinationals devoted a higher share of manufacturing FDIs also in electronic components (7.9\%) as well as food and tobacco (5.5\%), while their counterparts from Europe invested more in metals and plastics sectors. ${ }^{19}$

\subsection{Is there convergence in European and North American FDI patterns?}

The observed differences in FDI patterns of European and North American economies appear to persist over time. ${ }^{20}$ Figure 7 illustrates this by computing the difference between

\footnotetext{
${ }^{19}$ Using data in terms of capital invested as opposed to the number of projects leaves the distribution of FDIs from European and North American MNCs across sectors largely unaltered. See Figs. 5 and 6 in the Online Appendix.

20 The analysis of differences in European and North American FDIs over time needs to be placed in the context of the overall change in the portfolio of cross-border value-added activities undertaken by MNCs in the examined period. Broadly speaking, there is evidence of a remarkable fall in the share of world FDIs in manufacturing and in R\&D with an acceleration after the outbreak of the global financial crisis. This fall has been compensated by significant increases in the overall importance of FDIs related to DDT, ICT infrastructures, sales and logistics, while FDIs in headquarter services have approximately maintained their weight over time. These changes appear to have characterised FDI patterns of most MNCs originating from advanced countries, including European and North American ones, although with some differences in intensity. Data on changes in the composition of FDIs by main business activities are available upon request. Explaining these changes is beyond the scope of this paper.
} 


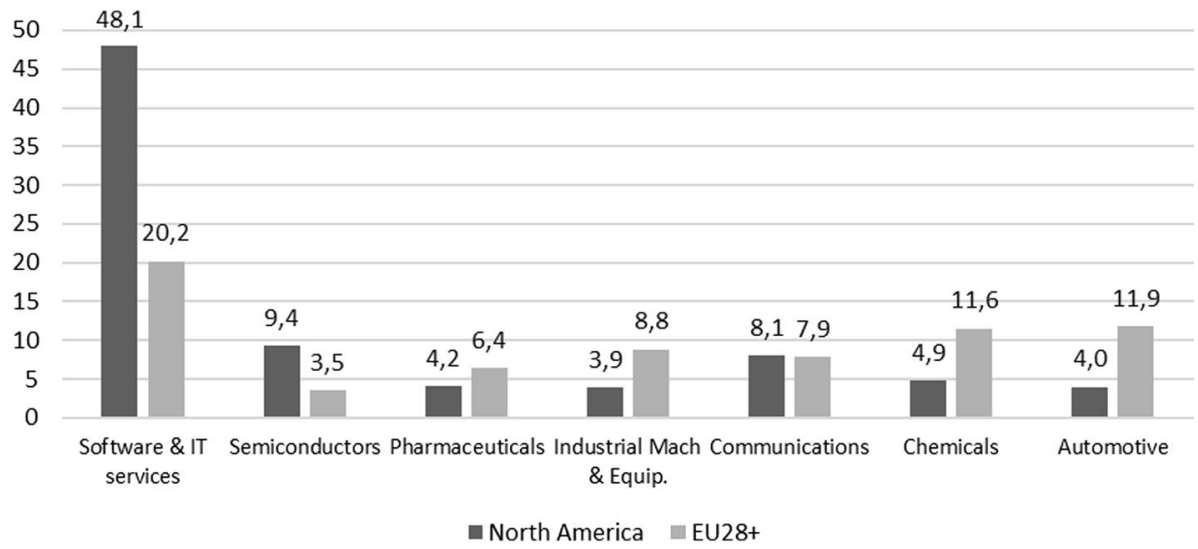

Fig. 5 Share (\%) of FDIs in $R \& D$ and DDT activities from North America and Europe towards China and India by industry of destination (based on number of FDI projects), 2003-2017. Source: Authors' elaboration on fDi Markets database

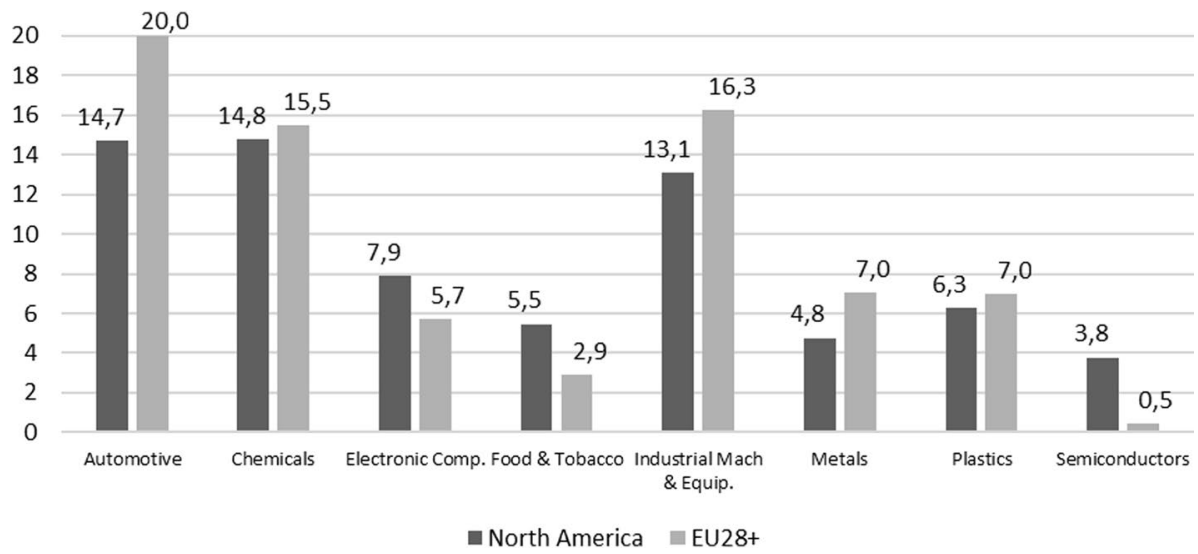

Fig. 6 Share (\%) of FDIs in manufacturing activity from North America and Europe towards China and India by industry of destination (based on number of FDI projects), 2003-2017. Source: Authors' elaboration on fDi Markets database

North America's and Europe's share of outward FDIs per year-in both knowledge and manufacturing activities - directed to the world economy (Panel a) or to the emerging countries only (Panel b), respectively. These figures allow to appreciate the evolution of the overall gap between North American and European regions in terms of FDIs related to different value chain activities, thus clarifying even better the different global investment strategies pursued by the MNCs headquartered in the two advanced regions.

Panel (a) of Fig. 7 highlights the constantly higher North America's share of outward FDIs in knowledge-intensive activities with respect to Europe over time. A positive gap can always be observed here, spanning from a minimum of $7 \%$ at the beginning of the period to a maximum of $8 \%$ in 2005 , a minimum of $4 \%$ in 2011 concluding the period with a gap of about $4.5 \%$. Panel (a) also shows, quite symmetrically, that North America constantly exhibited a much lower share of manufacturing FDI projects out of its total FDIs 


\section{Panel (a). North American FDI premia (relative to EU FDIs) towards the World}

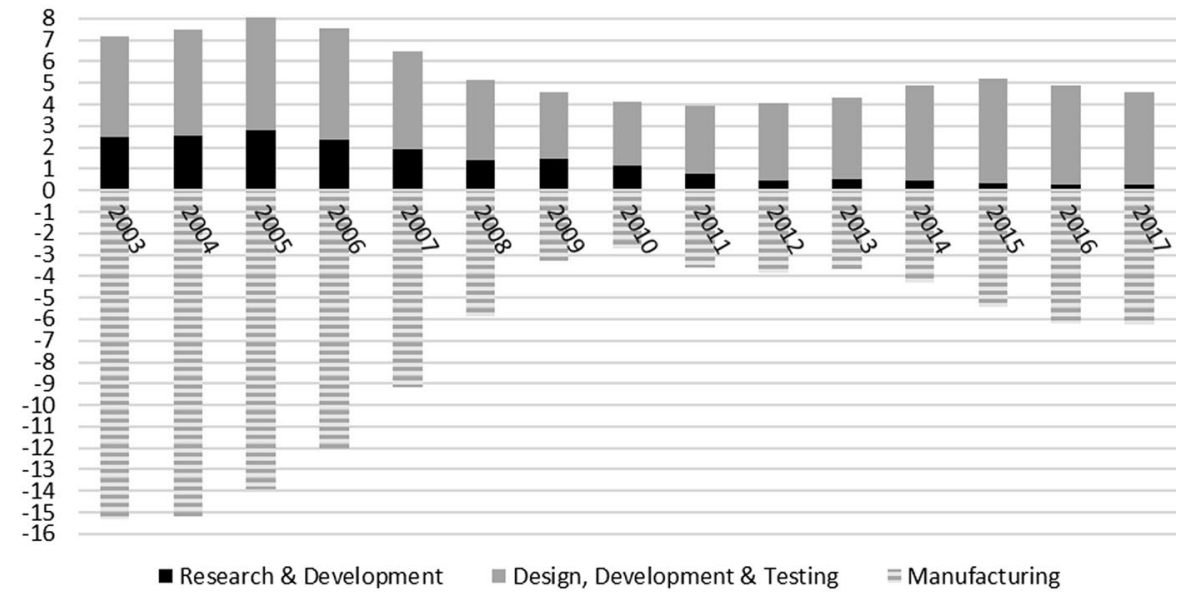

Panel (b). North American FDI premia (relative to EU FDIs) towards Emerging economies

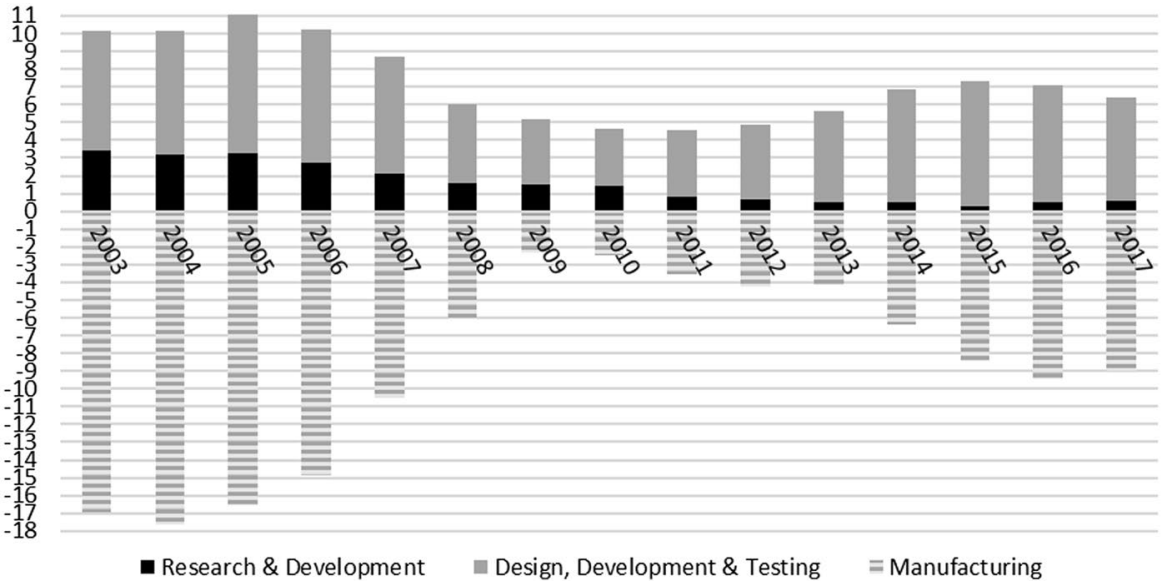

Fig. 7 Difference between the North America's and Europe's share of outward FDIs (based on number of FDI projects) in technological and manufacturing activities (\% shares by activity per year) towards the World (a) and Emerging economies (b), 3-year moving average, 2003-2017 Source: Authors' elaboration on fDi Markets database

per year with respect to Europe. We can thus observe a persistently negative and very substantial gap between North American and European FDIs in manufacturing. As shown, the negative gap reached a maximum of $15 \%$ at the beginning of the period, shrank to $3-4 \%$ at the turn of the first decade, and bounced back to $6 \%$ in in 2017.

These different patterns of FDIs in both manufacturing and technological activities are even magnified when looking at investment flows towards the emerging economies (Fig. 7b). On the one hand, the positive gap between North American and European FDIs shares in R\&D and DDT activities persist over time at higher levels here than observed in the case of FDIs towards the whole world, varying from $10 \%$ at the beginning of the period, reaching a maximum of $11 \%$ in 2005, a minimum of $4-5 \%$ in 2010-2011, and concluding the period with 
more than $6 \%$. On the other hand, the magnitude of the negative divide between North America and Europe is also larger and constantly negative, although with greater discontinuities in time, when focusing on the share of manufacturing FDIs directed in emerging economies.

The evidence we have shown induces us to reconsider some of the conclusions by Hymer and Rowthorn (1970) of more than 50 years ago (and discussed in the review section) on the patterns of FDIs by North American and European firms. What Hymer and Rowthorn had not foreseen is the remarkable divergence in the composition and geographical direction of FDI flows. In fact, we have highlighted a much greater and persisting attitude of North American MNCs to offshore knowledge-intensive activities - especially DDT-towards foreign locations, with a particularly high involvement of emerging regions of the world. We also found that, quite symmetrically to the evidence illustrated in the case of knowledge-intensive activities, European MNCs exhibit a greater propensity to offshore manufacturing plants, especially towards emerging areas. Lastly, it is worth emphasizing that these divergences in FDI patterns appear to persist over a relatively long period of time - that is, since the turn of the XXI century -, except for the years immediately preceding the great financial crisis. ${ }^{21}$

\subsection{A focus on top North American and European MNCs in emerging regions}

What is the role played by leading MNCs in shaping these patterns of FDIs? To address this question, Table 4 provides a picture of the cross-border investment flows promoted by the top $10 \mathrm{MNCs}$ based in the two advanced regions, as well as the number of North American and European parent companies detected by the fDi Market database. The Top 10 MNCs are ranked according to the number and share of FDIs towards Emerging economies - split according to the value chain activity involved, i.e., R\&D, DDT, and manufacturing (the same figures in terms of capital values are reported by Table 4 in the Online Appendix). The total number of parent companies having at least one investment in an emerging country is recorded and compared with the overall number of parent companies originating from each of the two regions. Several features related to the MNCs' area of origin emerge from Table 4.

First, the sectoral distribution of leading MNCs based in Europe and in North America is quite different. The top 10 North American MNCs investing in emerging economies are mainly active in semiconductors, software and computer programming services; conversely, European MNCs are more present in pharmaceutical and automotive industries.

Second, while most of the top 10 European MNCs are based in Germany, France, United Kingdom and Switzerland, almost all of the top 10 North American companies are US-based. The only exception in the latter case is Magna International, a Canadian company which produces automotive components and occupies the eighth position in the ranking in terms of number of manufacturing FDIs. ${ }^{22}$

\footnotetext{
${ }^{21}$ Data on monetary values of FDIs broadly confirm this picture with the relevant exception of the phase at the turn of the second decade of the century (2009-11). Those years have been characterised by a sharper decline of European FDI shares in manufacturing, making (also) the difference between North America's and Europe's share of outward FDIs in the latter activity positive. This might reveal different reactions of MNCs based in Europe and North America in the face of the global crisis. See Fig. 7 in the Online Appendix for details.

22 Fiat Chrysler Automobiles (FCA) is headquartered in Amsterdam (Netherlands) and its financial headquarter is in London (UK), although being an Italian-American MNC born in October 2014 by the merger of Fiat (an Italian automobile company) and Chrysler (a US automobile company); fDi Markets database reports Italy as the country of origin of most FDIs by FCA, while a residual part has UK as country of origin. Nokia and Nokia Networks belong to the same corporate group although fDi Markets records them separately. DuPont and Dow Chemicals had completed a merger on September 2017 (Fortune, 2017). ArcelorMittal is headquartered in Luxembourg, although being a Franco-Indian group born after the takeover and merger of Arcelor, a Franco-Spanish company, by Indian-owned Mittal Steel company in 2006.
} 
Third, and consistently with our previous findings, the absolute number of North American parent companies involved in the internationalization of both R\&D and DDT activity is much higher than in the case of European MNCs. More precisely, the number of parent companies based in North America which have promoted at least one FDI in R\&D and DDT activities towards emerging countries is 298 and 1013, respectively; while it is 239 and 768, respectively, in the case of Europe. As a result, the share of North American parent companies investing in emerging economies in R\&D and DDT activities over the total number of parent companies based in North America is equal to $2.1 \%$ and $7.1 \%$, respectively, which is more than twice as high as the share of parent companies based in Europe (equal to 1 and $3.2 \%$, respectively). Notably, the opposite is true with regard to the parent companies investing in manufacturing offshoring, as almost one out of five European parent companies has promoted at least one manufacturing FDI towards emerging economies, while this percentage drops to less than $15 \%$ in the case of North American companies.

Fourth, the top North American MNCs promote a much higher number of cross-border investments in R\&D and DDT activities towards emerging countries than MNCs based in Europe. Once again, quite consistent with the evidence we have illustrated earlier, the scenario is reversed when it comes to the number of manufacturing FDIs: it is European MNCs that exhibit a higher number of FDIs in this domain.

Fifth, the top 10 North American MNCs systematically hold a larger share of the total number of FDIs in the examined period, as compared with top 10 European MNCs, particularly in the case of R\&D and DDT activities. However, the number of North American parent companies investing in Emerging areas of the world is systematically higher than in the case of European MNCs, when knowledge-intensive activities are considered. ${ }^{23}$

Overall, our evidence confirms the stronger projection of North American parent companies towards emerging economies, especially in the case of high value-added activities such as research, design and development. Nevertheless, diverging patterns of cross-border investments are not just driven by a handful of leading high-tech parent companies but emerges as a structural difference between the global investment strategies of US and European MNCs.

\section{Emerging competitors in FDI markets}

To fully appreciate the importance of the described FDI patterns undertaken by the most advanced economies, one needs to consider that new competitors have appeared on the global stage over the past decades. To this regard, a growing literature has emphasized the increasing role played by MNCs based in emerging economies, especially China and India (Amighini \& Franco, 2013; Amighini et al., 2014, 2015; Kedia et al., 2016; Verbeke $\&$ Kano, 2015). However, while the amount of outward FDIs from China experienced a

\footnotetext{
${ }^{23}$ When FDIs are expressed in monetary values, the role of top European MNCs appears to be much more substantial (see Table 4 in the Online Appendix). To illustrate, the capital invested of FDIs in R\&D activity by the top 5 MNCs based in Europe, i.e. Novartis (from Switzerland), British Gas Group (from United Kingdom), Sanofi-Aventis (from France), Siemens (from Germany) and Royal Dutch Shell (from the Netherlands), cover one third of total R\&D cross-border flows of investment towards emerging countries promoted by all European parent companies (this share is equal to $12.7 \%$ in terms of number of FDIs).
} 


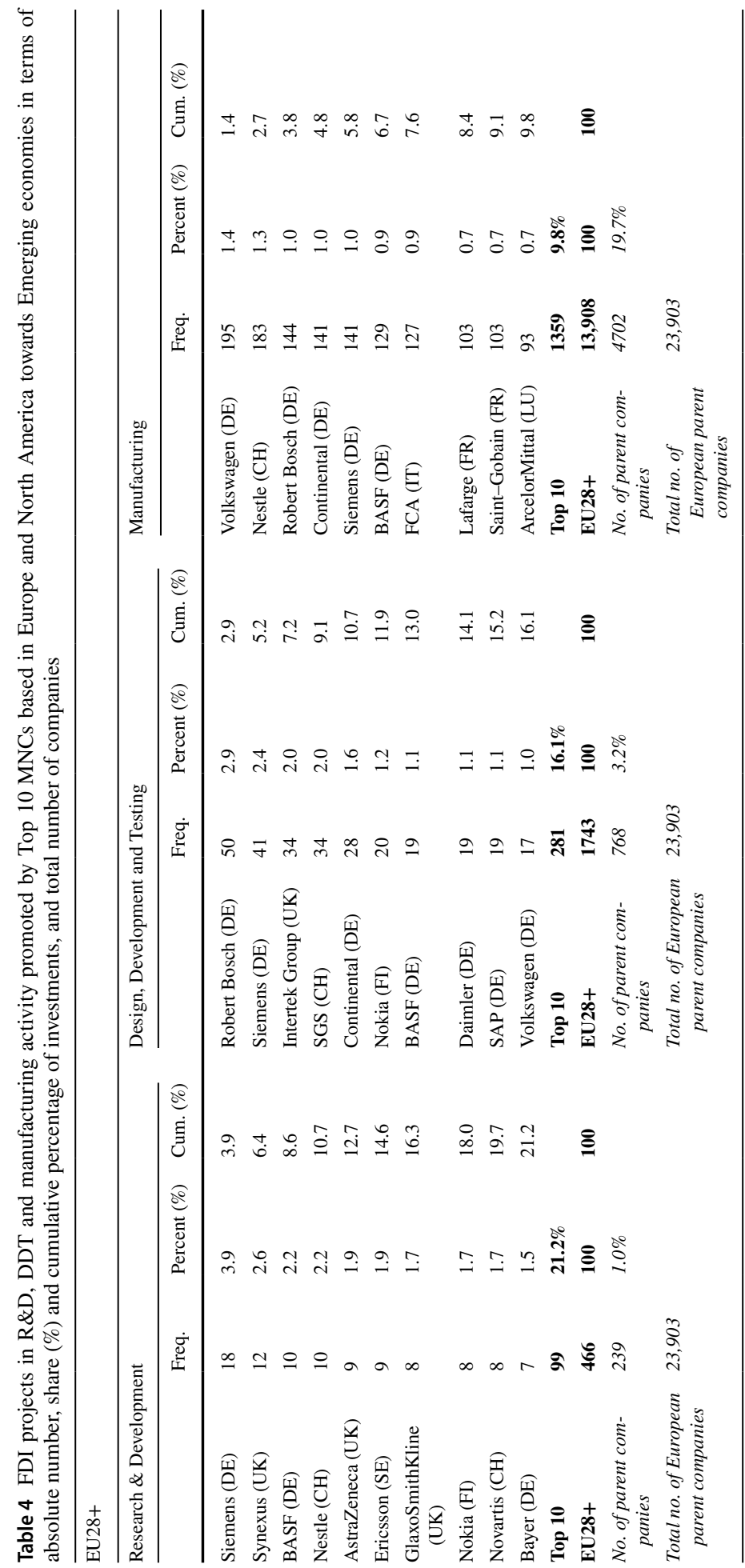




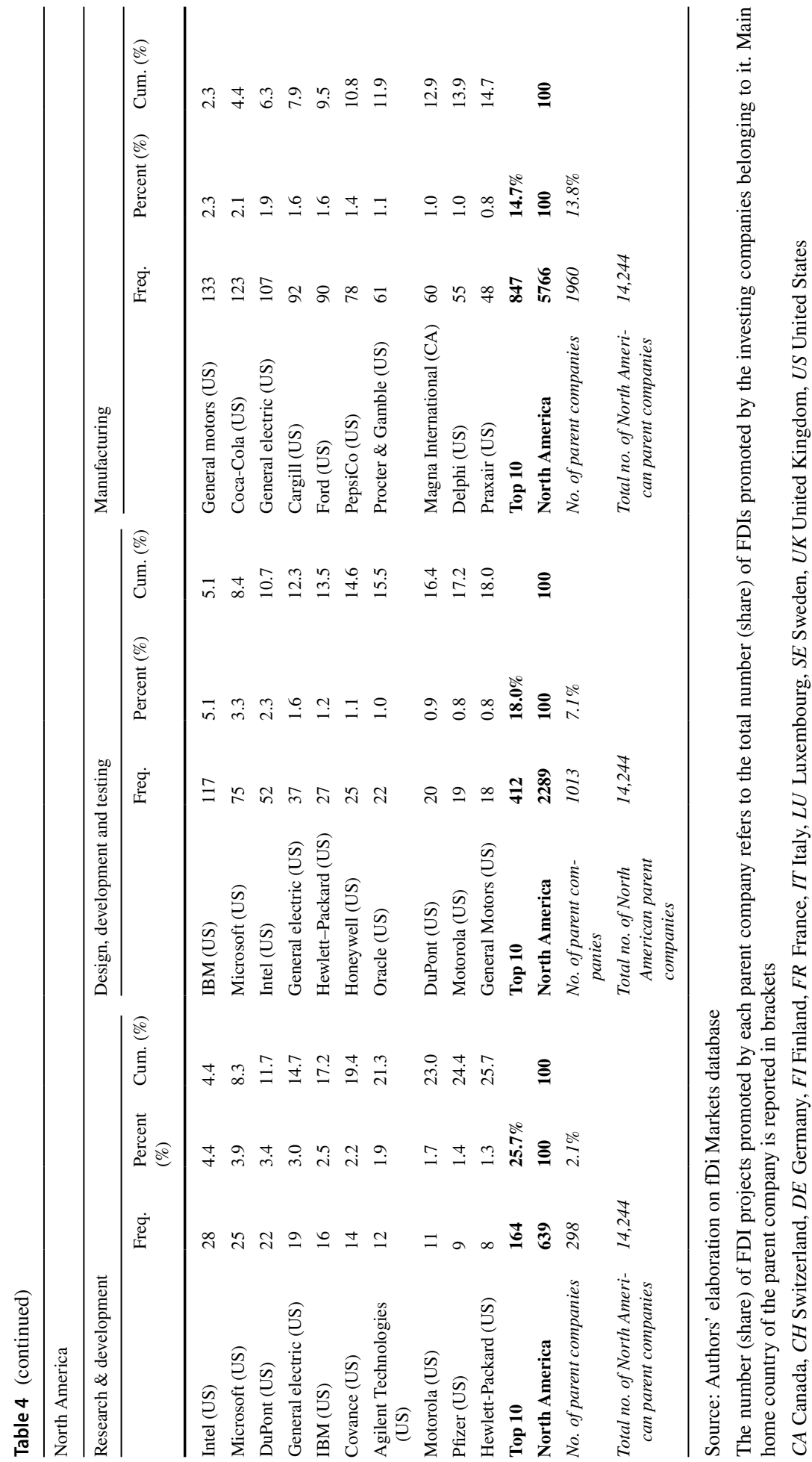


remarkable increase in the last two decades and especially since 2013, the pace of FDIs flow from India has been much slower. In particular, China accounted for $4.6 \%$ of total number of outward FDIs in 2017, up from slightly more than $1 \%$ in 2013 and $2.7 \%$ in $2013 .^{24}$ This makes China the largest world investor after the US $(21 \%)$, Germany $(10 \%)$, the UK (9.3\%), Japan (5.7\%) and France (5.4\%). Conversely, India's share of total outward FDI flows was equal to $2 \%$ in 2017, from about $1.5 \%$ in 2007 and down from a peak close to $3 \%$ registered in 2011. Accordingly, in this section we take a brief look to the FDI flows originating from China, with the aim to frame the comparison between the MNCs from Europe and North America within a more exhaustive picture.

Chinese MNCs' remarkable rise is most apparent when looking at their increasing internationalization of technological activities. In fact, since 2016 China has overtaken France in terms of total number of outward FDIs in R\&D and Design and Development functions; the following year China's share of world outward FDIs in technological activities (equal to 7.4\%) reached and surpassed Japan's (6.1\%) and the UK's (7.2\%) (Fig. 8). This makes of China the world largest cross-border investor in knowledge-intensive activities after the US and Germany, which in 2017 registered a share of world FDI outflows equal to 30 and $12 \%$ respectively. ${ }^{25}$ The number of outward FDIs in manufacturing activity promoted by Chinese MNCs also experienced a remarkable rise since 2014 , accounting in that year for $4.4 \%$ of total crossborder investments in this activity, up from 1.3\% in 2003. In 2017 China's share of manufacturing FDIs reached 6\%, after the US (15.2\%), Germany (13.7\%) and Japan (10.4\%). ${ }^{26}$

Most important for our purposes is the destination region of Chinese outward FDIs across technological and manufacturing functions. In this regard, two stylized facts emerge from the analysis of FDIs from the Asian giant. First, the bulk of FDIs in technological activity from China targeted advanced economies, especially the US and the UK, as well as Germany and Sweden. The largest amount of these FDIs took place in telecommunications, software \& IT services, and communication equipment (leading Chinese MNCs in these sectors are Huawei, ZTE and Baidu), as well as the automotive industry (Geely Holding Group, BAIC Group, CSGC) and of household appliances (Haier). Conversely, the share of technological FDIs towards emerging economies is relatively low (Fig. 9a), also because China itself represents the largest emerging economy of the globe. Consistently, the share of FDIs in technological activities from China towards emerging economies (24\% in 2017) is much lower than the European (47.2\%) and especially the North American (55.7\%) ones (see Table 2 in Sect. 4.1 of this work). As expected, India is the largest attractor of FDIs in R\&D and DDT activities from China, having drawn 32 FDI projects, i.e., $8 \%$ of technological FDIs from Chinese MNCs, over the whole period.

Second, the largest share of FDIs from China in manufacturing activity has emerging economies as a recipient, especially India, Russia, Indonesia, Brazil and Vietnam. These

\footnotetext{
${ }^{24}$ We avoid considering the outward FDIs from affiliates of MNCs headquartered in Switzerland, as well as in the Four Asian Tigers, because of the fiscal regime of these countries. In fact, these economies are often included in tax havens lists and their statistics on outward FDIs are therefore strongly upward biased by cross-border investments originating from offshore vehicles controlled by foreign MNCs (Desai et al., 2006; Hines, 2010; Hines \& Rice, 1994).

25 The role of China is only partially downscaled when looking at outward FDIs in terms of capital invested, according to which China accounts for 5.5\% of total FDI outflows in technological activities in 2017, after the US (30\%), Germany (15.3\%) and the UK (7.1\%) (Fig. 8 in the Online Appendix).

${ }^{26}$ When computing the share of total FDI outflows from China in terms of capital invested, this country emerges since 2014 as the second largest world investor, with a share reaching a peak equal to $14 \%$ in 2016 (the US one is $19.4 \%$ in the same year). Similarly, the share of outward FDIs in manufacturing from China in terms of capital invested was equal to $11.5 \%$ in 2017 , overtaken only by the US (15.2\%).
} 
countries draw $28 \%$ of manufacturing FDI projects from China (a share growing to $39 \%$ in terms of capital invested) over the whole period. The sectors most targeted by Chinese MNCs-e.g., China National Petroleum (CNPC) and China Petrochemical Corporation (Sinopec) - are in this case the metals and the mining ones, and to a lower extent the automotive industry (among the largest Chinese MNCs operating in the latter sector there are, e.g., Chery Automobile and Great Wall Motors (GWM)). It follows that, although the Asian giant is increasingly turning to the US and, to a lower extent, Canada and Germany to perform the manufacturing functions of its value chains, about $70 \%$ of manufacturing FDIs from China still target emerging economies (Fig. 9b). ${ }^{27}$

Overall, the internationalization of R\&D by Chinese MNCs thus seems to be still largely driven by a technological catching-up strategy aimed to tapping into the largest and most dynamic innovation hubs located in leading advanced countries (Awate et al., 2015; Steinberg et al., 2021; Zhao et al., 2021). This is in line with the objective of China to improve and consolidate its domestic innovation capabilities by fostering the technology transfer from its most innovative competitors through FDIs in research, design and development activities (Amendolagine et al., 2015, 2018). Accordingly, the FDI flow in knowledgeintensive activities from China towards other emerging economies is relatively negligible. In the next section we will try to account also for this evidence in discussing the potential implications of the examined FDI trajectories on the global race for competitiveness.

\section{Implications on the global race for competitiveness}

The evidence offered in the previous sections paves the way for a discussion on the potential consequences of the observed patterns on international knowledge transfers and on the possible gains which may derive for MNCs located on the two sides of the Atlantic. In what follows we draw on the literature on the internationalization of $R \& D$, on knowledge transfer mechanisms as well as on GVC studies to detect some key implications on the global race for competitiveness. As such, the following lines of argument can be intended more as subject matter for future research than as conclusive, evidence-based statements. From this perspective, the evidence discussed earlier points out at least five key issues that are at stake when it comes to the competitiveness of advanced economies.

First, the greater propensity to undertake R\&D FDIs in emerging countries that we observed in the case of North America's MNCs might reveal their higher capacity to exploit firm-specific technological advantages in fast growing markets as compared to European competitors This would translate into a greater capability of the US-based MNCs to adapt and customize domestically originated goods to the requirements of emerging markets, which often combine large size with highly dynamic demand growth and may hence facilitate the exploitation of economies of scale and scope for investors. Notably, the role played by adaptive $R \& D$ as a crucial asset in market penetration strategies has been widely illustrated especially in the case of China and India (Athreye et al., 2014; Chen, 2004; Gassmann \& Han, 2004; Haakonsson \& Ujjual, 2015; Kuemmerle, 1999; Kumar \& Saqib, 1996; Sun et al., 2006; Wang et al., 2012).

\footnotetext{
27 These results are also largely confirmed when looking at the data in terms of capital invested (Fig. 9 in the Online Appendix).
} 


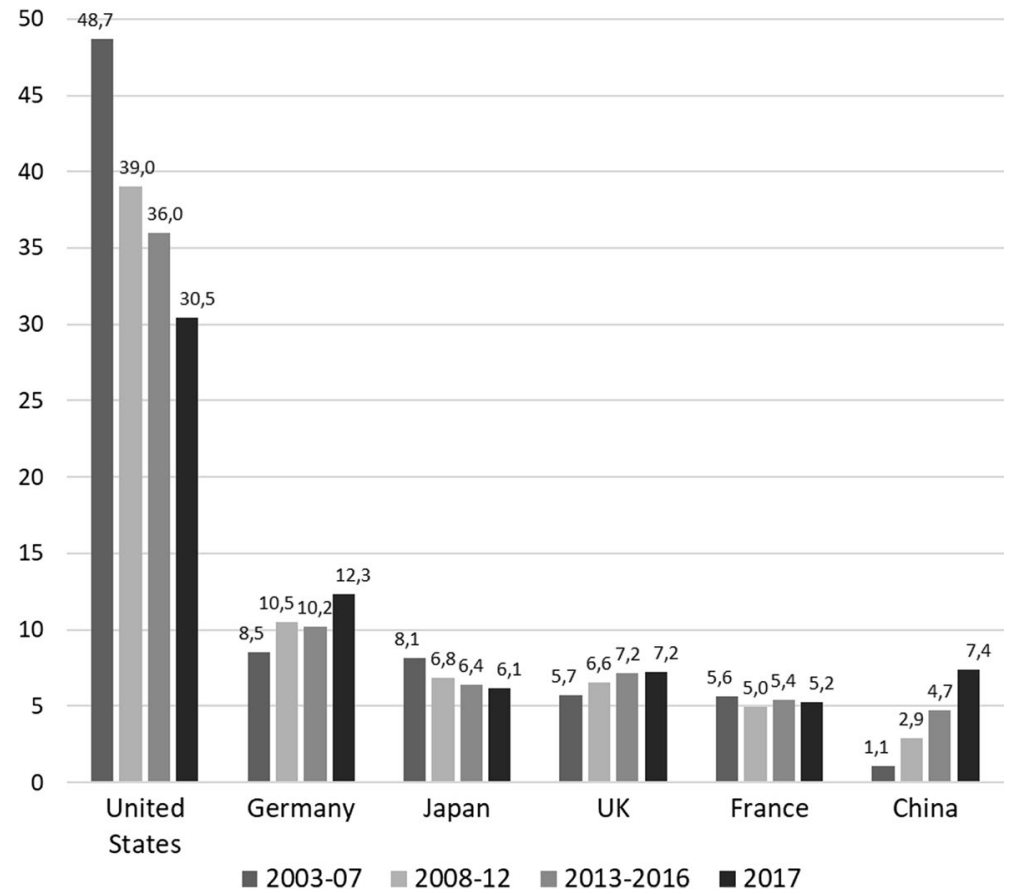

Fig. 8 Average share of global outward FDIs (computed in terms of number of FDI projects) in technological activities over different periods (\% by region of origin). Source: Authors' elaboration on fDi Markets database

\section{Panel (a). FDIs in R\&D and DDT activity}

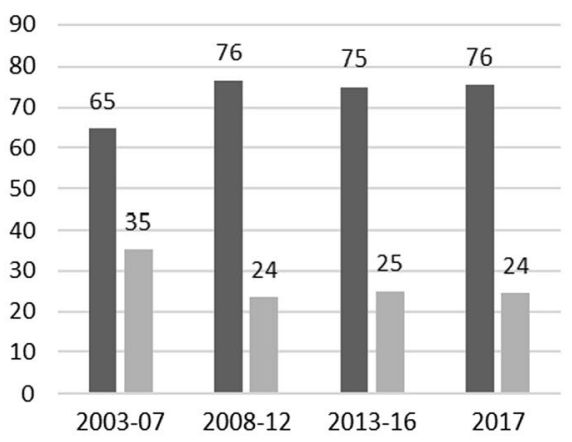

advanced economies as a recipient

Emerging economies as a recipient

\section{Panel (b). FDIs in manufacturing activity}

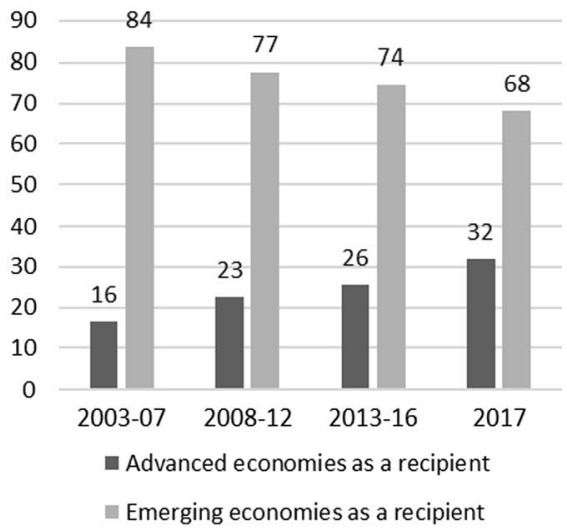

Fig. 9 Average share of outward FDIs from China (computed in terms of number of FDI projects) in technological (a) and manufacturing (b) activity over different periods (\% by region of destination) Source: Authors' elaboration on fDi Markets database 
Second, R\&D labs located in the most dynamic emerging economies may represent a fundamental means to tap into promising local technological capacities. In fact, these economies have emerged as new generators of knowledge which attracted increasing attention as destinations of asset-seeking and asset-augmenting FDIs by advanced countries' MNCs (Edler, 2008; Huggins et al., 2007; Kumar \& Aggarwal, 2005; Motohashi, 2015). Consistently, North American MNCs might benefit the most from "reverse knowledge transfer" (RKT) from foreign affiliates to parent companies, thanks to their greater involvement in R\&D FDIs in emerging countries that are endowed with high quality human capital and technical competencies. In fact, MNCs investing in these regions are likely to be better placed at increasing their expertise and innovation capacity, hence enriching the available technologies of the home country and enhancing firms' long-term competitiveness (Ambos et al., 2006; Belderbos et al., 2015; Griffith et al., 2006; Hamida \& Piscitello, 2013; Rabbiosi \& Santangelo, 2013).

Further support to this perspective is offered by the recent literature on "reverse innovation", which can be triggered by the promoting knowledge-seeking investments in countries that are set on a trajectory of technological catch-up (Govindarajan \& Ramamurti, 2011; Govindarajan \& Trimble, 2012; von Zedtwitz et al., 2015). In this case, MNCs based in advanced countries and investing in emerging regions may be enabled to develop innovation capacities that are bounced back to the advanced country, firstly to comply with requirements from national markets and then to satisfy global demand (Huang \& Li, 2019; Jha et al., 2018; von Zedtwitz \& Gassmann, 2016; Zhang \& Pearce, 2010; Zhao et al., 2020).

Third, important advantages may be associated to the localization of $R \& D F D I s$ in emerging economies characterized by strong mission-oriented structural policies, as it is particularly the case of Asian countries. In these contexts, the creation of knowledge sourcing opportunities is largely the result of conscious industrial and innovation policy efforts undertaken by local governments aimed at technology upgrading in GVCs (Lebdioui et al., 2021; Lee et al., 2021). This has been documented particularly in the case of China (Bruche, 2009; Haour \& Jolly, 2014; Liu \& Chen, 2005, 2012; Liu et al., 2011) and India (Awate et al., 2015; Jha et al., 2018; Kumaraswamy et al., 2012; Lema et al., 2015; Prabhu \& Jain, 2015). Crescenzi and Rodríguez-Pose (2017) have emphasized the substantial increase in public investments related to $R \& D$ activities in emerging economies and the availability of new high-quality scientific infrastructure, especially in fast-growing urban areas of China and India. Manning et al. (2008) stressed the large pools of highly skilled personnel available at relatively low cost, combined with a relative shortage of science and engineering talents in advanced economies, a factor underlined also by Lewin et al. (2009) and Awate and Mudambi (2018). In this regard, Arora and Badge (2010) recall the huge investments in IT-related and software services in India, while Haakonsson (2013) documented the large amount of biotechnology investments in China. One may thus suggest that FDIs accruing towards these countries are all the more likely to be associated with reverse knowledge transfer and reverse innovation practices. Consistently, recent studies highlighted that a growing share of cross-border investments in these countries, has a learning-oriented nature and, given the heightened global competitive pressure, is performed to generate new knowledge for the introduction of strategic innovation (Altenburg et al., 2008; Athreye et al., 2014; Bresciani \& Ferraris, 2016; Prashantham \& Dhanaraj, 2015).

In a similar vein, other streams of literature have highlighted the advantages associated with the exploitation of the opportunities offered by the newly organized National Systems of Innovation of emerging countries (Álvarez \& Marin, 2010; Jha et al., 2018; Liu \& Chen, 2012; Liu \& White, 2001; Lundvall et al., 2002). To this end, wholly-owned subsidiaries 
appear to be a prevailing strategy to quickly enter in new expanding markets and tap into knowledge assets of emerging economies (Awate, et al., 2015; Castellani \& Zanfei, 2006; Castellani et al., 2017; Chaturvedi \& Chataway, 2006; Mudambi et al., 2014; von Zedtwitz, 2004). Accordingly, the evidence provided on the geographical, functional and sectoral composition of FDIs originating from advanced economies indicates that it is more likely that MNCs based in North America will take benefit from innovation-oriented policies undertaken by emerging countries. This might further entail a stronger capability of North American multinationals to learn from managerial and innovation practices in host regions, promote forms of partnership with local partners and institutions, and leverage these assets to foster international technology transfers through backward linkages with parent companies.

Fourth, a pivotal role in the locational patterns of cross-border knowledge-sourcing investments is played by both external and internal agglomeration economies (Feldman $\&$ Kogler, 2010), i.e., the increasing returns arising from the spatial concentration of economic activities the MNCs benefit from, triggered by both inter- and intra-firm co-location of high value-added activities. Accordingly, MNCs tend to invest in countries, regions and cities well-endowed with advanced infrastructures and limited sunk and information costs (Henisz \& Delios, 2001; Mariotti \& Piscitello, 1995; McCann \& Acs, 2011), giving rise to a cumulative process of local clustering of innovation and thus to a geographical concentration of knowledge spillovers (Balland et al., 2015; Gertler, 2003; Le Duc \& Lindeque, 2018; Storper \& Venables, 2004; Vicente \& Suire, 2007). In this respect, recent studies have stressed that the effects of external agglomeration economies and intra-firm co-location phenomena differ according to the value chain activity offshored, affecting the locational pattern of investments related to different value-adding functions (Alcacer \& Delgado, 2016; Castellani \& Santangelo, 2017; Davids \& Frenken, 2018; Gray et al., 2015; Mudambi et al., 2018; Schubert et al., 2018). ${ }^{28}$ This is likely to explain the observed propensity of both European and US-based multinationals to concentrate a large share of both R\&D-related and manufacturing FDIs in specific sectors, namely automotive and industrial machinery (as well as chemicals) in the case of the Europeans; and high-tech electronic components in the case of US-based ones. Nonetheless, the much higher propensity of US-based multinationals to promote foreign investments in knowledge-intensive value chain activities next to manufacturing ones in emerging economies might signal their greater capability to take advantage of agglomeration economies and co-location dynamics in GVCs.

Fifth, technology-driven strategies co-exist, and combine, with cost-reduction objectives. Indeed, the role of global efficiency-seeking investment strategies meant to gain a (labour) cost advantage thanks to the wage differential between countries at different stages of development turned out to be crucial also for the locational choices of the most knowledge-intensive business activities. More precisely, a large literature has shown that abundant well-educated employees to be hired at relatively lower wages constitutes a further element which spurs MNCs to move the most upstream value chain activities towards emerging regions with the aim of reducing the total R\&D costs (Athukorala \& Kohpaiboon, 2010; Chen, 2004; Demirbag \& Glaister, 2010; Doh et al., 2009; Lewin \& Peeters, 2006; Manning et al., 2008; Sachwald, 2008; Schmiele, 2012). In this respect, insights from the

\footnotetext{
${ }_{28}$ For example, Ivarsson et al. (2017) have found that, using data on Sweden's 17 largest MNCs in 2013, co-location between R\&D and manufacturing stages of production turns out to be critical not just for adapting existing products but mainly for developing new ones for the global market.
} 
recent work by Buckley et al. (2020) are noteworthy. Assuming a value chain perspective and taking full advantage of the World Input-Output Tables (WIOD), the authors provide an empirical analysis able to trace the evolution of the incomes of workers performing different tasks in production in both advanced and emerging countries. Most important, they find a rapid convergence in real (per capita) income earned by workers involved in fabrication activities (i.e., manufacturing and assembly stages of the GVC) in emerging countries relative to advanced regions, while such a convergence is shown to be very much slower for workers performing knowledge-intensive activities (namely both pre- and post-production functions, as R\&D and design on the one side and marketing and distribution on the other side). In other terms, the patterns of employees' remuneration convergence between emerging and advanced economies show a significant heterogeneity according to the value chain function carried out by workers.

Accordingly, US-based MNCs might be better able to combine major cost-based advantages with innovation capacities. Along with the advantage deriving from offshoring $\mathrm{R} \& \mathrm{D}$ activities in those countries which are making major efforts in climbing the technological ladder, US MNCs are likely to benefit more from dislocating in emerging economies those knowledge-intensive value chain functions for which a higher labour cost gap is detected. In other words, high offshoring-intensive North American MNCs pursue an internationalization trajectory which may allow them to gain both a technological advantage-due to their stronger propensity to tap into fast-growing emerging economies' pool of knowledge; and a crucial cost-based competitive advantage - given by a still prominent wage differential between highly qualified knowledge workers in advanced and emerging economiescompared to European rivals.

In this scenario, the growing competition in FDI markets due to the remarkable rise and expansion of MNCs from emerging economies, especially from India and, even more so, from China, is likely to pose major challenges to both North American and European MNCs. In fact, we showed that these fast-growing emerging countries are not only huge attractors of cross-border investment flows from advanced economies, but they are also fearsome competitors in industries previously dominated mainly by MNCs headquartered in the US, as well as in Germany, the UK and France. On the one hand, to the extent that US-based MNCs would benefit the most from foreign knowledge sources and reverse transfers of technology and capabilities from emerging markets, this would make them better equipped to cope with growing competition from Chinese MNEs. On the other hand, the analysis of the sectoral composition of FDI projects from China shows that the industries at the technological frontier in which Chinese multinationals are gaining ever more ground largely overlap with those in which US-based multinationals are acting as incumbents, namely, software \& IT services, semiconductors and electronic components. Quite symmetrically, we showed that Chinese investments in manufacturing activities largely occur in less developed countries, suggesting that China is competing quite hard also in the direction of cost reduction in the fabrication of goods and services. This is likely to be a critical issue especially for European MNCs, which rely on emerging countries for efficiency-seeking FDIs in manufacturing much more than North American ones. These considerations further corroborate the importance of future research on global competitive dynamics in those industries and countries in which the role of China is likely to be ever more disruptive for both North American and European MNCs, although for different reasons. 


\section{Conclusions}

In this work we have shown that MNCs headquartered in Europe and in North America have undertaken rather different patterns of outward FDIs in key value chain activities. Despite being big investors in technological activities, European MNCs turn out to rely on emerging economies more to offshore production than to set up R\&D labs in these countries. By contrast, North American MNCs are more prone to engage in outward investments towards the most dynamic emerging economies, especially China and India. Most important, the difference between the shares of outward FDIs undertaken by North American and European MNCs appear to be even higher when focusing on knowledge-intensive investments, showing a much stronger propensity of the former to involve emerging companies in their global networks of innovation. In other words, North American companies are definitely more prone to offshore their production and technological activities, especially towards the emerging countries, than is the case of European firms. This diversity is apparent when considering the top MNCs of the two areas, but it clearly emerges also when accounting for the whole population of North American and European MNCs; moreover, it persists throughout the relatively long period under observation.

In the light of this evidence, we built on the literature on the internationalization of $\mathrm{R} \& \mathrm{D}$, knowledge transmission mechanisms as well as GVC-oriented studies to identify key factors concerning the race for competitiveness among world's leading regions, in a scenario in which the growing competition from emerging economies' MNCs-especially from China- poses major challenges to both North American and European actors. In particular, the discussion offered suggests that the higher propensity of US-based corporations to involve emerging economies in their innovation networks might provide them with five main advantages over their European counterparts. First, they could be better placed for adapting their products to the needs of large and fast-growing emerging markets. Second, they might be better positioned to tap into dynamic and promising sources of knowledge of the most dynamics economies, therefore benefitting the most from reverse transfers of innovation. Third, they could benefit more from the upgrading efforts undertaken by the most dynamic developing economies, which in recent years have adopted important industrial and innovation policies and modernized their national innovation systems. Fourth, their higher propensity to co-locate R\&D next to manufacturing activities in fast-growing emerging countries - especially in high-tech electronics - may allow them to take greater advantage from agglomeration economies. Fifth, they can benefit from lower income convergence of workers in knowledge-intensive activities, allowing them to leverage low-cost, high-quality human capital.

While our empirical investigation offers an insightful picture on the diversity in internationalization strategies by MNCs based in Europe and North America, we are fully aware of the limitations of our analysis.

A first limitation is that our analysis refers only to greenfield investments. In fact, our data source (fDiMarkets) does not include brownfield investments. Unfortunately, data on M\&As available from other sources do not allow to distinguish the value chain activity they are aimed to perform, a piece of information that is crucial for our comparative analysis. While disregarding brownfield investments may be less of a problem when considering FDIs targeting emerging and developing countries - which is a key focus of this paper -, their exclusion certainly limits our ability to capture important motives underlying crossborder investments, such as financial speculation, the search for reduction in production 
capacity and/or the consolidation of market power in foreign markets (the latter playing a major role in the case of M\&As; see Ietto-Gillies, 2019). Future research should overcome this drawback either by extending the coverage of data sources or by complementing quantitative analyses with case studies on how value chain activities are controlled by means of M\&As.

A second limitation comes from disregarding Non-Equity Modes (NEMs) of international production. While this work focuses on FDI as the essential tool for MNCs to penetrate foreign markets, access low-cost production factors, and source strategic assets for knowledge generation (Wilkins, 2001), in last decades the international fragmentation of production has given NEMs an increasing relevance (UNCTAD, 2011, 2020). Although FDIs and international alliances tend to complement one another, not accounting for NEMs may lead to offer an incomplete picture of modern internationalization trajectories and make it more difficult to draw conclusions from the observed patterns.

A third limitation concerns the level of aggregation of the analysis. Although we do account for some heterogeneity across countries and sectors, our analysis remains focused on FDI trajectories across macro-regions in search for regularities and converging patterns between the two main advanced areas of the world. Paying greater attention to sources of heterogeneity across and within countries might further enrich the overall picture and improve our understanding of the observed patterns.

Lastly, a fourth limitation concerns the descriptive nature of the investigation. The latter should be conceived as a first step in the direction of restoring a debate on internationalization decisions in a comparative perspective in the era of GVCs. Accordingly, future research should further explore the reasons underlying the patterns observed and especially the impact on the economic and technological performance of firms and country of origin. In this regard, our contribution offers a relevant starting point for more refined empirical analyses.

Supplementary Information The online version contains supplementary material available at https://doi. org/10.1007/s10961-021-09911-z.

Open Access This article is licensed under a Creative Commons Attribution 4.0 International License, which permits use, sharing, adaptation, distribution and reproduction in any medium or format, as long as you give appropriate credit to the original author(s) and the source, provide a link to the Creative Commons licence, and indicate if changes were made. The images or other third party material in this article are included in the article's Creative Commons licence, unless indicated otherwise in a credit line to the material. If material is not included in the article's Creative Commons licence and your intended use is not permitted by statutory regulation or exceeds the permitted use, you will need to obtain permission directly from the copyright holder. To view a copy of this licence, visit http://creativecommons.org/licenses/by/4.0/.

\section{References}

Alcacer, J., \& Delgado, M. (2016). Spatial organization of firms and location choices through the value chain. Management Science, 62(11), 3213-3234.

Altenburg, T., Schmitz, H., \& Stamm, A. (2008). Breakthrough China's and India's transition from production to innovation. World Development, 36(2), 325-344.

Álvarez, I., \& Cantwell, J. (2011). International integration and mandates of innovative subsidiaries in Spain. International Journal of Institutions and Economies, 3(3), 415-444. 
Álvarez, I., \& Marin, R. (2010). Entry modes and national systems of innovation. Journal of International Management, 16(4), 340-353.

Ambos, T. C., Ambos, B., \& Schlegelmilch, B. B. (2006). Learning from foreign subsidiaries: An empirical investigation of headquarters' benefits from reverse knowledge transfers. International Business Review, 15(3), 294-312.

Amendolagine, V., Cozza, C., \& Rabellotti, R. (2015). Chinese and Indian multinationals: A firm-level analysis of their investments in Europe. Global Economic Review, 44(4), 452-469.

Amendolagine, V., Giuliani, E., Martinelli, A., \& Rabellotti, R. (2018). Chinese and Indian MNEs' shopping spree in advanced countries. How good is it for their innovative output? Journal of Economic Geography, 18(5), 1149-1176.

Amighini, A., Cozza, C., Giuliani, E., Rabellotti, R., \& Scalera, V. G. (2015). Multinational enterprises from emerging economies: What theories suggest, what evidence shows. A literature review. Economia e Politica Industriale, 42, 343-370.

Amighini, A., Cozza, C., Rabellotti, R., \& Sanfilippo, M. (2014). Investigating Chinese outward foreign direct investments: How can firm-level data help? China \& World Economy, 22(6), 44-63.

Amighini, A., \& Franco, C. (2013). A sector perspective on Chinese outward FDI: The automotive case. China Economic Review, 27(C), 148-161.

Arora A., \& Badge S. K. (2010). Human capital and the Indian software industry (NBER Working Paper, 16167).

Ascani, A., Crescenzi, R., \& Iammarino, S. (2016). What drives European multinationals to the European Union neighbouring countries? A mixed-methods analysis of Italian investment strategies. Environment and Planning c: Government and Policy, 34(4), 656-675.

Athukorala, P. C., \& Kohpaiboon, A. (2010). Globalization of R\&D by US-based multinational enterprises. Research Policy, 39(10), 1335-1347.

Athreye, S., Tuncay-Celikel, A., \& Ujjual, V. (2014). Internationalisation of R\&D into emerging markets: Fiat's R\&D in Brazil, Turkey and India. Long Range Planning, 47(1-2), 100-114.

Audretsch, D. B., Lehmann, E. E., \& Wright, M. (2014). Technology transfer in a global economy. Journal of Technology Transfer, 39(3), 301-312.

Awate, S., Larsen, M. M., \& Mudambi, R. (2015). Accessing vs sourcing knowledge: A comparative study of R\&D internationalization between emerging and advanced economy firms. Journal of International Business Studies, 46(1), 63-86.

Awate, S., \& Mudambi, R. (2018). On the geography of emerging industry technological networks: The breadth and depth of patented innovations. Journal of Economic Geography, 18(2), 391-419.

Baldwin, R. (2006). Globalisation: The great unbundling(s). Economic Council of Finland, 20(3), 5-47.

Baldwin, R. (2013). Trade and industrialisation after globalisation's 2nd unbundling. In R. C. Feenstra \& A. M. Taylor (Eds.), Globalization in an age of crisis: multilateral economic cooperation in the twenty-first century (pp. 165-212). University of Chicago Press.

Balland, P. A., Boschma, R., \& Frenken, K. (2015). Proximity and innovation: From statics to dynamics. Regional Studies, 49(6), 907-920.

Behrman, J. N., \& Fischer, W. A. (1980a). Overseas $R \& D$ activities of transnational corporations. Oelgeschlager, Gunn \& Hain.

Behrman, J. N., \& Fischer, W. A. (1980b). Transnational corporations: Market orientations and R\&D abroad. Columbia Journal of World Business, 15(3), 55-60.

Belderbos, R., Leten, B., \& Suzuki, S. (2013). How global is R\&D? Firm-level determinants of homecountry bias in R\&D. Journal of International Business Studies, 44(8), 765-786.

Belderbos, R., Lokshin, B., \& Sadowski, B. (2015). The returns to foreign R\&D. Journal of International Business Studies, 46(1), 491-504.

Belderbos, R., Sleuwaegen, L., Somers, D., \& De Backer, K. (2016). Where do locate innovative activities in global value chain. Does co-location matter? (OECD Science, Technology and Industry Policy Papers, 30). OECD Publishing.

Bernard, A. B., Smeets, V., \& Warzynski, F. (2017). Rethinking deindustrialization. Economic Policy, $32,5-38$.

Blanc, H., \& Sierra, C. (1999). The internationalisation of R\&D by multinationals: A trade-off between external and internal proximity. Cambridge Journal of Economics, 23(2), 187-206.

Bresciani, S., \& Ferraris, A. (2016). Innovation-receiving subsidiaries and dual embeddedness: Impact on business performance. Baltic Journal of Management, 11(1), 108-130.

Bruche, G. (2009). The Emergence of China and India as New Competitors in MNCs' Innovation Networks. Competition \& Change, 13(3), 267-288.

Buckley, P. J. (2011). International integration and coordination in the global factory. Management International Review, 51(2), 269-283. 
Buckley, P. J., \& Strange, R. (2015). The governance of the global factory: Location and control of world economic activity. Academy of Management Perspectives, 29(2), 237-249.

Buckley, P. J., Strange, R., Timmer, M. P., \& de Vries, G. J. (2020). Catching-up in the global factory: Analysis and policy implications. Journal of International Business Policy, 3, 79-106. https://doi. org/10.1057/s42214-020-00047-9

Cantwell, J. (1995). The globalisation of technology: What remains of the product cycle model? Cambridge Journal of Economics, 19(1), 155-174.

Cantwell, J., Dunning, J. H., \& Janne, O. (2002). Evolution of multinational corporate technological systems in the UK and US. Journal of Interdisciplinary Economics, 13(1-2), 135-163.

Cantwell, J., Dunning, J. H., \& Janne, O. (2004). Towards a technology-seeking explanation of U.S. direct investment in the United Kingdom. Journal of International Management, 10(1), 5-20.

Cantwell, J., \& Janne, O. (1999). Technological globalisation and innovative centres: The role of corporate technological leadership and locational hierarchy. Research Policy, 28(2-3), 119-144.

Cantwell, J., \& Janne, O. (2000). The role of multinational corporations and nation states in the globalisation of innovatory capacity: The European perspective. Technology Analysis and Strategic Management, 12(2), 243-262.

Cantwell, J., \& Mudambi, R. (2005). MNE competence-creating subsidiary mandates. Strategic Management Journal, 26(12), 1109-1128.

Cantwell, J., \& Piscitello, L. (2000). Accumulating technological competence: Its changing impact on corporate diversification and internationalization. Industrial and Corporate Change, 9(1), 21-51.

Castellani, D. (2018). The changing geography of innovation and the multinational enterprise. In G. Cook, J. Johns, F. McDonald, J. Beaverstock, \& N. Pandit (Eds.), The Routledge companion to the geography of international business (pp. 454-474). Routledge.

Castellani, D., Jimenez, A., \& Zanfei, A. (2013). How remote are R\&D labs? Distance factors and international innovative activities. Journal of International Business Studies, 44(7), 649-675.

Castellani, D., Meliciani, V., \& Mirra, L. (2016). The determinants of inward foreign direct investment in business services across European regions. Regional Studies, 50(4), 671-691.

Castellani, D., \& Pieri, F. (2013). R\&D offshoring and the productivity growth of European regions. Research Policy, 42(9), 1581-1594.

Castellani, D., \& Pieri, F. (2015). Outward investments and productivity. Evidence from European regions. Regional Studies, 50(12), 1945-1964.

Castellani, D., Rullani, E., \& Zanfei, A. (2017). Districts, multinationals and global/digital networks. Economia e Politica Industriale, 44(4), 429-447.

Castellani, D., \& Santangelo, G. (2017). Quo vadis? Cities and the location of cross-border activities. In Paper presented at the 44th AIB-UK\&I Conference and 6th Reading IB Conference, Henley Business School, 6-8 April. Reading.

Castellani, D., \& Zanfei, A. (2006). Multinational firms. Edward Elgar.

Celi, G., Ginzburg A., Guarascio D., \& Simonazzi A. (2018). Crisis in the European monetary union: A core-periphery perspective. Routledge.

Chaturvedi, K., \& Chataway, J. (2006). Strategic integration of knowledge in Indian pharmaceutical firms: Creating competencies for innovation. International Journal of Business Innovation and Research, 1(1-2), 27-50.

Chen, S. H. (2004). Taiwanese IT firms' offshore R\&D in China and the connection with the global innovation network. Research Policy, 33(2), 337-349.

Chen, Y. C. (2008). Why do multinational corporations locate their advanced R\&D centres in Beijing? Journal of Development Studies, 44(5), 622-644.

Crescenzi, R., Pietrobelli, C., \& Rabellotti, R. (2014). Innovation drivers, value chains and the geography of multinational corporations in Europe. Journal of Economic Geography, 14(6), 1053-1086.

Crescenzi, R., Pietrobelli, C., \& Rabellotti, R. (2015). Location strategies of multinationals from emerging countries in the EU regions (LSE 'Europe in Question' Discussion Paper, 93/2015). http://aei.pitt. edu/93655/1/LEQSPaper93.pdf

Crescenzi, R., \& Rodríguez-Pose, A. (2017). The geography of innovation in China and India. International Journal of Urban and Regional Research, 41(6), 1010-1027.

Dachs, B., Borowiecki, M., Kinkel, S., \& Schmall, T. C. (2012). The offshoring of production activities in European manufacturing (MPRA Working Paper, 42973). Munich.

Dachs, B., Ebersberger, B., Kinkel, S., \& Som, O. (2015). The effects of production offshoring on R\&D and innovation in the home country. Economia e Politica Industriale-Journal of Industrial and Business Studies, 42(1), 9-31.

Dachs, B., Stehrer, R., \& Zahradnik, G. (Eds.) (2014). The internationalization of business R\&D. Edward Elgar. 
Davids, M., \& Frenken, K. (2018). Proximity, knowledge base and the innovation process: Towards an integrated framework. Regional Studies, 52(1), 23-34.

De Beule, F., \& Van Beveren, I. (2019). Sources of open innovation in foreign subsidiaries: An enriched typology. International Business Review, 28(1), 135-147.

De Marchi, V., Di Maria, E., \& Ponte, S. (2014). Multinational firms and the management of global networks: Insights from global value chain studies. Advances in International Management, 27, 463-486.

Demirbag, M., \& Glaister, K. W. (2010). Factors determining offshore location choice for R\&D projects: A comparative study of developed and emerging regions. Journal of Management Studies, 47(8), 1534-1560.

De Prato, G., \& Nepelski, D. (2014). Global technological collaboration network: Network analysis of international co-inventions. Journal of Technology Transfer, 39(3), 358-375.

Desai, M., Foley, C., \& Hines, J. R. (2006). The demand for tax haven operations. Journal of Public Economics, 90(3), 513-531.

Doh, J. P., Bunyaratavej, K., \& Hahn, E. D. (2009). Separable but not equal: The location determinants of discrete services offshoring activities. Journal of International Business Studies, 40(6), 926-943.

Dunning, J. H. (1977). Trade, location of economic activity and the MNE: A search for an eclectic approach. In B. Ohlin, P. O. Hesselborn, \& P. M. Wijkman (Eds.), The international allocation of economic activity (pp. 395-431). Macmillan.

Dunning, J. H. (1980). Toward and eclectic theory of international production: Some empirical tests. Journal of International Business Studies, 11(1), 9-31.

Dunning, J. H. (1993). Multinational enterprises and the global economy. Addison Wesley.

Dunning, J. H., \& Narula, R. (1995). The R\&D activities of foreign firms in the US. International Studies in Management \& Organisation, 25(1-2), 39-73.

Edler, J. (2008). Creative internationalization: Widening the perspectives on analysis and policy regarding international R\&D activities. Journal of Technology Transfer, 33(4), 337-352.

Ernst, D. (2006). Innovation offshoring: Asia's emerging role in global innovation networks (East-West Center Special Report, 10). East-West Center.

Feenstra, R. C. (1998). Integration of trade and disintegration of production in the global economy. Journal of Economic Perspectives, 12(4), 31-50.

Feldman, M. P., \& Kogler, D. F. (2010). Stylized facts in the geography of innovation. In B. H. Hall \& N. Rosenberg (Eds.), Handbook of the economics of innovation (Vol. 1, pp. 381-410). North-Holland.

Fortune. (2017). Dow chemical and dupont have completed a $\$ 130$ billion merger. Retrieved June 7 , 2021, from https://fortune.com/2017/09/01/dow-dupont-merger-complete/

Franko, L. G. (1976). The European multinationals: A renewed challenge to American and British big business. Greylock Publishers.

Gassmann, O., \& Han, Z. (2004). Motivations and barriers of foreign R\&D activities in China. $R \& D$ Management, 34(4), 423-437.

Gereffi, G., Humphrey, J., \& Sturgeon, T. (2005). The governance of global value chains. Review of International Political Economy, 12(1), 78-104.

Gertler, M. S. (2003). Tacit knowledge and the economic geography of context, or the undefinable tacitness of being (there). Journal of Economic Geography, 3(1), 75-99.

Govindarajan, V., \& Ramamurti, R. (2011). Reverse innovation, emerging markets, and global strategy. Global Strategy Journal, 1(3-4), 191-205.

Govindarajan, V., \& Trimble, C. (2012). Reverse innovation: Create far from home. Harvard Business Review Press.

Gray, J. V., Siemsen, E., \& Vasudeva, G. (2015). Colocation still matters: Conformance quality and the interdependence of R\&D and manufacturing in the pharmaceutical industry. Management Science, 61(11), 2760-2781.

Griffith, R., Harrison, R., \& Van Reenen, J. (2006). How special is the special relationship? Using the impact of US R\&D spillovers on UK firms as a test of technology sourcing. American Economic Review, 96(5), 1859-1875.

Haakonsson, S. J. (2013). Offshoring of innovation: Global innovation networks in the Danish biotech industry. In T. Pedersen, L. Bals, P. D. Ø. Jensen, \& M. M. Larsen (Eds.), The offshoring challenge: Strategic design and innovation for tomorrow's organization. Springer.

Haakonsson, S. J., \& Ujjual, V. (2015). Internationalisation of R\&D: New insights into multinational enterprises' R\&D strategies in emerging markets. Management Revue, 26(2), 101-122.

Hamida, L. B., \& Piscitello, L. (2013). The impact of foreign R\&D activities on the MNC's performance at home: Evidence from the case of Swiss manufacturing firms. Revue D'économie Industrielle, $143,11-33$. 
Haour, G., \& Jolly, D. (2014). China: The next innovation hot spot for the world. Journal of Business Strategy, 35(1), 2-8.

Henisz, W. J., \& Delios, A. (2001). Uncertainty, imitation, and plant location: Japanese multinational corporations, 1990-1996. Administrative Science Quarterly, 46(3), 443-475.

Hines, J. R. (2010). Treasure Islands. Journal of Economic Perspectives, 24(4), 103-126.

Hines, J. R., \& Rice, E. M. (1994). Fiscal paradise: Foreign tax havens and American business. Quarterly Journal of Economics, 109(1), 149-182.

Huang, G. K., \& Li, J. (2019). Adopting knowledge from reverse innovations? Transnational patents and signaling from an emerging economy. Journal of International Business Studies, 50(7), 1078-1102.

Huggins, R., Demirbag, M., \& Ratcheva, V. I. (2007). Global knowledge and R\&D foreign direct investment flows: Recent patterns in Asia Pacific, Europe and North America. International Review of Applied Economics, 21(3), 437-451.

Hymer, S. H. (1972). The multinational corporation and the law of uneven development. In J. N. Bhagwati (Ed.), Economics and world order. From the 1970s to the 1990s (pp. 113-140). The Free Press.

Hymer, S. H. (1976). The international operations of national firms: A study of foreign direct investment. MIT Press.

Hymer, S. H., \& Rowthorn, R. (1970). Multinational corporation and international oligopoly: The NonAmerican challenge. In C. P. Kindleberger (Ed.), The international corporation (pp. 57-91). MIT Press.

Ietto-Gillies, G. (2019). Transnational corporations and international production: Concepts. Edward Elgar.

IMF. (2019). World economic outlook 2019: global manufacturing downturn, rising trade barriers. International Monetary Fund.

Ivarsson, I., Alvstam, G., \& Vahlne, J. E. (2017). Global technology development by colocating R\&D and manufacturing: The case of Swedish manufacturing MNEs. Industrial and Corporate Change, 26(1), 149-168.

Jha, S. K., Dhanaraj, C., \& Krishnan, R. T. (2018). From arbitrage to global innovation: Evolution of multinational R\&D in emerging markets. Management International Review, 58(4), 633-661.

Kedia, B. L., Rhew, N. D., Gaffney, N. T., \& Clampit, J. A. (2016). Emerging market multinationals: Coopetition for global growth. Thunderbird International Business Review, 58, 515-526.

Kindleberger, C. P. (1969). The theory of direct investment. In C. P. Kindleberger (Ed.), American business abroad. Yale University Press.

Kuemmerle, W. (1999). The drivers of foreign direct investment into research and development: An empirical investigation. Journal of International Business Studies, 30(1), 1-24.

Kumar, N., \& Aggarwal, A. (2005). Liberalization, outward orientation and in-house R\&D activity of multinational and local firms: A quantitative exploration for Indian manufacturing. Research Policy, 34(4), $441-460$.

Kumar, N., \& Saqib, M. (1996). Firm size, opportunities for adaptation, and in-house R\&D activity in developing countries: The case of Indian manufacturing. Research Policy, 25(5), 712-722.

Kumaraswamy, A., Mudambi, R., Saranga, H., \& Tripathy, A. (2012). Catch-up strategies in the Indian auto components industry: Domestic firms' responses to market liberalization. Journal of International Business Studies, 43(4), 368-395.

Laurens, P., Le Bas, C., Schoen, A., Villard, L., \& Larédo, P. (2015). The rate and motives of the internationalisation of large firm R\&D (1994-2005): Towards a turning point? Research Policy, 44(3), $765-776$.

Le Bas, C., \& Sierra, C. (2002). Location versus country advantages' in R\&D activities: Some further results on multinationals' locational strategies. Research Policy, 31(4), 589-609.

Lebdioui, A., Lee, K., \& Pietrobelli, C. (2021). Local-foreign technology interface, resource-based development, and industrial policy: How Chile and Malaysia are escaping the middle-income trap. Journal of Technology Transfer, 46(3), 660-685.

Le Duc, N., \& Lindeque, J. (2018). Proximity and multinational enterprise co-location in clusters: A multiple case study of Dutch science parks. Industry and Innovation, 25(3), 282-307.

Lee, J. D., Lee, K., Meissner, D., Radosevic, S., \& Vonortas, N. S. (2021). Local capacity, innovative entrepreneurial places and global connections: An overview. Journal of Technology Transfer, 46(3), 563-573.

Lema, R., Quadros, R., \& Schmitz, H. (2015). Reorganising global value chains and building innovation capabilities in Brazil and India. Research Policy, 44(7), 1376-1386.

Lewin, A. Y., Massini, S., \& Peeters, C. (2009). Why are companies offshoring innovation? The emerging global race for talent. Journal of International Business Studies, 40(6), 901-925. 
Lewin, A. Y., \& Peeters, C. (2006). Offshoring work: Business hype or the onset of fundamental transformation? Long Range Planning, 39(3), 221-239.

Liu, M. C., \& Chen, S. H. (2005). International R\&D deployment and locational advantage of developing countries: A case study of Taiwan. In T. Ito \& A. K. Rose (Eds.), International trade in east Asia (pp. 81-108). University of Chicago Press.

Liu, M. C., \& Chen, S. H. (2012). MNCs' offshore R\&D networks in host country's regional innovation system: The case of Taiwan-based firms in China. Research Policy, 41(6), 1107-1120.

Liu, F. C., Simon, D. F., Sun, Y. T., \& Cao, C. (2011). China's innovation policies: Evolution, institutional structure, and trajectory. Research Policy, 40(7), 917-931.

Liu, X., \& White, S. (2001). Comparing innovation systems: A framework and application to China's transitional context. Research Policy, 30(7), 1091-1114.

Lundvall, B. A., Johnson, B., Andersen, E. S., \& Dalum, B. (2002). National systems of production, innovation and competence building. Research Policy, 31(2), 213-231.

Manning, S., Massini, S., \& Lewin, A. Y. (2008). A dynamic perspective on next-generation offshoring: The global sourcing of science and engineering talent. Academy of Management Perspectives, 22(3), 35-54.

Mariotti, S., \& Piscitello, L. (1995). Information costs and location of FDIs within the host country: Empirical evidence from Italy. Journal of International Business Studies, 26(2), 815-841.

McCann, P., \& Acs, Z. (2011). Globalization: Countries, cities and multinationals. Regional Studies, 45(1), 17-32.

Meyer, K. E., Mudambi, R., \& Narula, R. (2011). Multinational enterprises and local contexts: The opportunities and challenges of multiple embeddedness. Journal of Management Studies, 48(2), 235-252.

Motohashi, K. (2015). Global business strategy. Multinational Corporations Venturing into Emerging Markets.

Mudambi, R. (2008) Location, control and innovation in knowledge-intensive industries. Journal of Economic Geography, 8, 699-725.

Mudambi, R., Narula, R., \& Santangelo, G. D. (2018). Location, collocation and innovation by multinational enterprises: A research agenda. Industry and Innovation, 25(3), 229-241.

Mudambi, R., Piscitello, L., \& Rabbiosi, L. (2014). Reverse knowledge transfer in MNEs: Subsidiary innovativeness and entry modes. Long Range Planning, 47(1), 49-63.

Narula, R., \& Michel, J. (2010). Reverse knowledge transfer and its implications for European policy. In P. Ahrweiler (Ed.), Innovation in Complex Social Systems (pp. 122-136). Routledge.

Narula, R., \& Zanfei, A. (2005). Globalization of Innovation: The role of multinational enterprises. In J. Fagerberg, D. Mowery, \& R. Nelson (Eds.), The Oxford handbook of innovation (pp. 318-345). Oxford University Press.

OECD. (2008). The internationalisation of business R\&D: Evidence. OECD.

Papanastassiou, M., Pearce, R., \& Zanfei, A. (2020). Changing perspectives on the internationalization of R\&D and innovation by multinational enterprises: A review of the literature. Journal of International Business Studies, 51(4), 623-664.

Patel, P. (2011). Location of innovative activities of EU large firms (SPRU Working Paper Series, 190). http://www.sussex.ac.uk/spru/documents/sewp190.pdf

Pearce, R. D. (1999). Decentralised R\&D and strategic competitiveness: Globalised approaches to generation and use of technology in multinational enterprises (MNEs). Research Policy, 28(2-3), 157-178.

Pearce, R., \& Papanastassiou, M. (1999). Overseas R\&D and the strategic evolution of MNEs: Evidence from laboratories in the UK. Research Policy, 28(1), 23-41.

Phene, A., \& Tallman, S. (2018). Subsidiary development of new technologies: Managing technological changes in multinational and geographic space. Journal of Economic Geography, 18(5), 1121-1148.

Prabhu, J., \& Jain, S. (2015). Innovation and entrepreneurship in India: Understanding jugaad. Asia Pacific Journal of Management, 32(4), 843-868.

Prashantham, S., \& Dhanaraj, C. (2015). MNE ties and new venture internationalization: Exploratory insights from India. Asia Pacific Journal of Management, 32(4), 901-924.

Rabbiosi, L., \& Santangelo, G. D. (2013). Parent company benefits from reverse knowledge transfer: The role of the liability of newness in MNEs. Journal of World Business, 48(1), 160-170.

Rama, R. (2008). Foreign investment innovation: A review of selected policies. Journal of Technology Transfer, 33(4), 353-363.

Ramasamy, B., Yeung, M., \& Laforet, S. (2012). China's outward foreign direct investment: Location choice and firm ownership. Journal of World Business, 47(1), 17-25.

Rammer, C., \& Schmiele, A. (2008). Globalisation of innovation in SMEs: Why they go abroad and what they bring back. Applied Economics Quarterly, 59(Supplement), 173-212. 
Reddy, P. (1997). New trends in globalization of corporate R\&D and implications for innovation capability in host countries: A survey from India. World Development, 25(11), 1821-1837.

Reddy, P. (2011). Global innovation in emerging economies. Routledge.

Sachwald, F. (2008). Location choices within global innovation networks: The case of Europe. Journal of Technology Transfer, 33(4), 364-378.

Saliola, F., \& Zanfei, A. (2009). Multinational firms, global value chains and the organization of knowledge transfer. Research Policy, 38(2), 369-381.

Schmiele, A. (2012). Drivers for international innovation activities in developed and emerging countries. Journal of Technology Transfer, 37(1), 98-123.

Schubert, T., Baier, E., \& Rammer, C. (2018). Firm capabilities, technological dynamism and the internationalisation of innovation: A behavioural approach. Journal of International Business Studies, 49(1), 70-95.

Servan-Schreiber, J. J. (1968). The American challenge. Harnish Hamilton.

Siedschlag, I., Smith, D., Turcu, C., \& Zhang, X. (2013). What determines the location choice of R\&D activities by multinational firms? Research Policy, 42(8), 1420-1430.

Steinberg, P. J., Urbig, D., Procher, V. D., \& Volkmann, C. (2021). Knowledge transfer and home-market innovativeness: A comparison of emerging and advanced economy multinationals. Journal of International Management. https://doi.org/10.1016/j.intman.2021.100873

Stopford, J. M., \& Wells, L. T. (1972). Managing the multinational enterprise: Organization of the firm and ownership of the subsidiary. Basic Books.

Storper, M., \& Venables, A. J. (2004). Buzz: Face-to-face contact and the urban economy. Journal of Economic Geography, 4(4), 351-370.

Sturgeon, T., \& Gereffi, G. (2009). Measuring success in the global economy: International trade, industrial upgrading, and business function outsourcing in global value chains. Transnational Corporations, 18, 1-35.

Sun, Y., Du, D., \& Huang, L. (2006). Foreign R\&D in developing countries: Empirical evidence from Shanghai, China. China Review, 6(1), 67-91.

Sutherland, D., \& Anderson, J. (2014). The pitfalls of using foreign direct investment data to measure Chinese multinational enterprise activity. China Quarterly, 221, 21-48.

UNCTAD. (2005). World investment report 2005. Transnational Corporations and the Internationalization of $R \& D$.

UNCTAD (2011). World investment report 2011. Non-equity modes of international production and development. United Nations.

UNCTAD (2013). World investment report 2013. Global value chains: Investment and trade for development. United Nations.

UNCTAD (2020). World investment report 2020. International production beyond the pandemic. United Nations.

Verbeke, A., \& Kano, L. (2015). The new internalization theory and multinational enterprises from emerging economies: A business history perspective. The Business History Review, 89(3), 415-445.

Vernon, R. (1966). International Investment and International Trade in the Product Cycle. Quarterly Journal of Economics, 80(2), 190-207.

Vernon, R. (1979). The product cycle hypothesis in a new international environment. Oxford Bulletin of Economics and Statistics, 41(4), 255-267.

Vicente, J., \& Suire, R. (2007). Informational cascades versus network externalities in locational choice: Evidence of "ICT clusters" formation and stability. Regional Studies, 41(2), 173-184.

von Zedtwitz, M. (2004). Managing foreign R\&D laboratories in China. R\&D Management, 34(4), 439-452.

von Zedtwitz, M., Corsi, S., Søberg, P. V., \& Frega, R. (2015). A typology of reverse innovation. Journal of Product Innovation Management, 32(1), 12-28.

von Zedtwitz, M., \& Gassmann, O. (2016). Global corporate R\&D to and from emerging countries. In S. Dutta, B. Lanvin, \& S. Wunsch-Vincent (Eds.), The global innovation index 2016 (pp. 125-131). Johnson Cornell University.

Wang, J., Xue, L., \& Liang, Z. (2012). Multinational R\&D in China: From home-country based to hostcountry-based. Innovation: Management, Policy \& Practice, 14(2), 192-202.

Wilkins, M. (2001). The history of multinational enterprise. In A. M. Rugman \& T. L. Brewer (Eds.), The Oxford handbook of international business (pp. 3-35). Oxford University Press.

Zanfei, A. (2000). Transnational firms and the changing organization of innovative activities. Cambridge Journal of Economics, 24(5), 515-542.

Zanfei, A., Coveri, A., \& Pianta, P. (2019). FDI patterns and global value chains in the digital economy (Working Papers Series in Economics, Mathematics and Statistics, 3). University of Urbino. 
Zhang, S., \& Pearce, R. (2010). Sources of technology and the strategic role of MNE subsidiaries in China. Multinational Business Review, 18(3), 49-72.

Zhao, S., Liu, X., Andersson, U., \& Shenkar, O. (2021). Knowledge management of emerging economy multinationals. Journal of World Business. https://doi.org/10.1016/j.jwb.2021.101255

Zhao, S., Tan, H., Papanastassiou, M., \& Harzing, A.-W. (2020). The internationalization of innovation towards the South: A historical case study of a global pharmaceutical corporation in China (19932017). Asia Pacific Journal of Management, 37, 553-585.

Publisher's Note Springer Nature remains neutral with regard to jurisdictional claims in published maps and institutional affiliations. 